\title{
Frequency dependent cross-shore suspended sediment transport. 1. A non-barred shoreface
}

\author{
Philip D. Osborne and Brian Greenwood \\ Scarborough College Coastal Research Group, University of Toronto, Scarborough, Ont. MIC IA4, Canada
}

(Received June 14, 1991; revision accepted December 5, 1991)

\begin{abstract}
Osborne, P.D. and Greenwood, B., 1992. Frequency dependent cross-shore suspended sediment transport. 1. A non-barred shoreface. Mar. Geol., 106: 1-24.
\end{abstract}

The local, time-varying and time-averaged suspended sediment transports across a marine, non-barred shoreface were obtained from field measurements of the near-bed velocity and sediment concentration vectors using electromagnetic current meters and optical backscatterance suspended solids sensors. Co-spectral analyses of velocity and sediment concentration revealed the contribution's of waves of different frequencies to the total transport; the transport attributable to quasi-steady currents was determined from the produst of the time-averaged cross-shore velocity and sediment concentration. Estimates of the local, time-integrated sediment volume flux (total and net) and the associated erosion or accretion were determined using depth-of-activity rods.

Suspended sediment transport was associated with: (1) local wind-forced waves; (2) swell; (3) low frequency waves (groupbound long waves) and (4) offshore-directed mean currents (undertow). These transport components varied spatially and temporally in response to changes in the wave height to water depth ratio. The local net oscillatory sediment transport rate at wind-wave and swell-wave frequencies was directed onshore predominantly, and increased as water depth decrcased in association with wave shoaling. The local mean sediment transport rate was predominantly offshore and dominated the net transport rate wherever wave-induced components were weak relative to the mean currents. Under breaking waves the suspended sediment transport contribution associated with wind-waves and swell-waves was reduced as a result of dissipation. The net suspended sediment transport rate exhibited a distinct vertical structure, reflecting the balance at each elevation between the opposing mean and oscillatory components of transport. The local time-averaged total and net sediment volume flux and resulting erosion and accretion patterns support the hypothesis of a near balance in sediment flux for the complete storm event.

\section{Introduction}

The sediment transport processes responsible for maintaining equilibrium profiles on both nonbarred and barred shorefaces remain poorly defined. Theory, which suggests that sediment transport on non-barred beaches is controlled by a simple balance between some perturbation in the dominant oscillatory velocity field and gravitational constraints is in qualitative agreement with

Correspondence to: B. Greenwood, University of Toronto, Scarborough College Coastal Res. Gr., Department of Geography, 1265 Military Trail, Scarborough, Ont. M1C 1A4, Canada. observed sediment behaviour (e.g. Bagnold, 1963, 1966; Bowen, 1980a,b; Bailard, 1981). However, this explanation is complicated by a nearshore velocity field composed of temporally and spatially varying oscillatory and quasi-steady components (e.g. Greenwood and Osborne, 1990a). The frequency distribution of cross-shore velocity vectors at a point, for example, is typically non-Gaussian, characterized by a non-zero mean and a marked skewness (e.g. Guza and Thornton, 1985; Doering and Bowen, 1985; Doering, 1988; Greenwood and Osborne, 1990b). Mcre importantly, sediment concentrations near the bed respond in a rather complex way to changes both in the instantaneous velocity (e.g. Huntley and Hanes, 1987; Doering 
and Bowen, 1989; Greenwood et al., 1990) and the form of the bottom boundary (e.g. Inman and Bowen, 1963; Sleath, 1982; Nielsen et al., 1979. 1982). Peaks in sediment concentration appear to be associated with individual wave cycles, wave groups (Doering and Bowen, 1989; Greenwood et al., 1990, 1991a,b; Osborne et al., 1990) and low frequency waves (Hanes and Huntley, 1986; Beach and Sternberg, 1988; Osborne et al., 1990), but no simple correlation with wave or current motion has emerged. Direct field measurement of sediment transport rates are urgently required to resolve the relative contributions of the various mechanisms proposed to the sediment transport maintaining a shoreface profile in quasi-equilibrium.

The aims of this paper are: (1) to identify crossshore suspended sediment transport mechanisms; (2) to define their relative importance in controlling the net cross-shore flux of sediment; and (3) to relate the net flux to observed morphological changes in a marine, non-barred shoreface. Rapid response sensors were uscid curing a storm to obtain field measurements of the near-bed, crossshore velocity and the suspended sediment concentration necessary to calculate local, time-varying fluxes of suspended sediment. Time-integrated sediment volume fluxes and local scour and accretion patterns were also determined for comparison with the measured net sediment transport rates and to document the morphological response to the sediment transport.

\section{Location of study}

Data for this study were collected from a nonbarred, marine nearshore environment during a field experiment conducted at Queensland Beach, Nova Scotia, Canada (Fig. 1), as part of the C-COAST Programme (see Greenwood et al., 1990, 1991a,b). Situated at the head of St. Margaret's Bay, the beach is exposed to the Atlantic Ocean through a narrow opening that substantially restricts the directional spread of the incident wave field. The shoreface is relatively steep and concave upwards (slope $\approx 0.10$ near the shoreline, decreasing to a slope $\approx 0.03$ further offshore-Fig. 2). It is composed of fine-to-medium, moderately sorted sand (Table 1) overlying cobbles; grain-size distri-

\section{TABLE 1}

Grain size characteristics of the shoreface at Queensland Beach. Note: samples were dry sieved at $1 / 4 \Phi$ intervals and statistics computed by the method of moments

\begin{tabular}{|c|c|c|c|c|}
\hline \multirow{2}{*}{$\begin{array}{l}\text { Location } \\
\text { (m) }\end{array}$} & \multicolumn{2}{|c|}{ Mean size } & \multirow{2}{*}{$\begin{array}{l}\text { Sorting } \\
\Phi\end{array}$} & \multirow{2}{*}{$\begin{array}{l}\text { Skewnes } \\
\Phi\end{array}$} \\
\hline & $\Phi$ & $\mathrm{mm}$ & & \\
\hline 140 & 2.62 & 0.16 & 0.69 & -2.03 \\
\hline 130 & 2.72 & 0.15 & 0.56 & -1.56 \\
\hline 120 & 2.71 & 0.15 & 0.57 & -1.20 \\
\hline 110 & 2.48 & 0.18 & 0.69 & -1.57 \\
\hline 100 & 2.55 & 0.17 & 0.62 & -2.19 \\
\hline 90 & 2.32 & 0.20 & 0.53 & -0.55 \\
\hline 80 & 2.11 & 0.23 & 0.56 & -0.28 \\
\hline 70 & 2.03 & 0.25 & 0.56 & -0.32 \\
\hline 60 & 2.04 & 0.24 & 0.63 & -0.65 \\
\hline 50 & 1.90 & 0.27 & 0.57 & -0.22 \\
\hline 40 & 1.77 & 0.29 & 0.53 & -0.43 \\
\hline 30 & 1.53 & 0.35 & 0.58 & -0.79 \\
\hline 20 & 1.76 & 0.30 & 0.68 & -1.57 \\
\hline 10 & 1.86 & 0.27 & 0.45 & -0.33 \\
\hline
\end{tabular}

butions are negatively skewed, a characteristic of wave-winnowed sediments (Greenwood and Davidson-Arnott, 1972). The Bay is meso-tidal (range $\approx 2 \mathrm{~m}$ at springs) and experiences periods

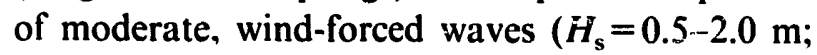
$T_{\mathrm{pk}}=4-8 \mathrm{~s}$ ) followed by periods of long-crested swell.

\section{Instrumentation and measurements}

\section{Wind}

Wind speed and direction were measured at the beach face with a Beaufort anemometer and wind vane.

\section{Water surface elevations}

Waves and mean water surface elevations were measured using piezo-resistive strain gauge transducers (Hazen et al., 1989); the transducers respond linearly and were calibrated in a $30 \mathrm{~m}$ deep tank using a Paroscientific Digi-quartz pressure transducer/computer (see Hazen et al., 1989). Pressure data were not corrected for effects of depth attenuation as these were negligible for the depths incurred in this study. 


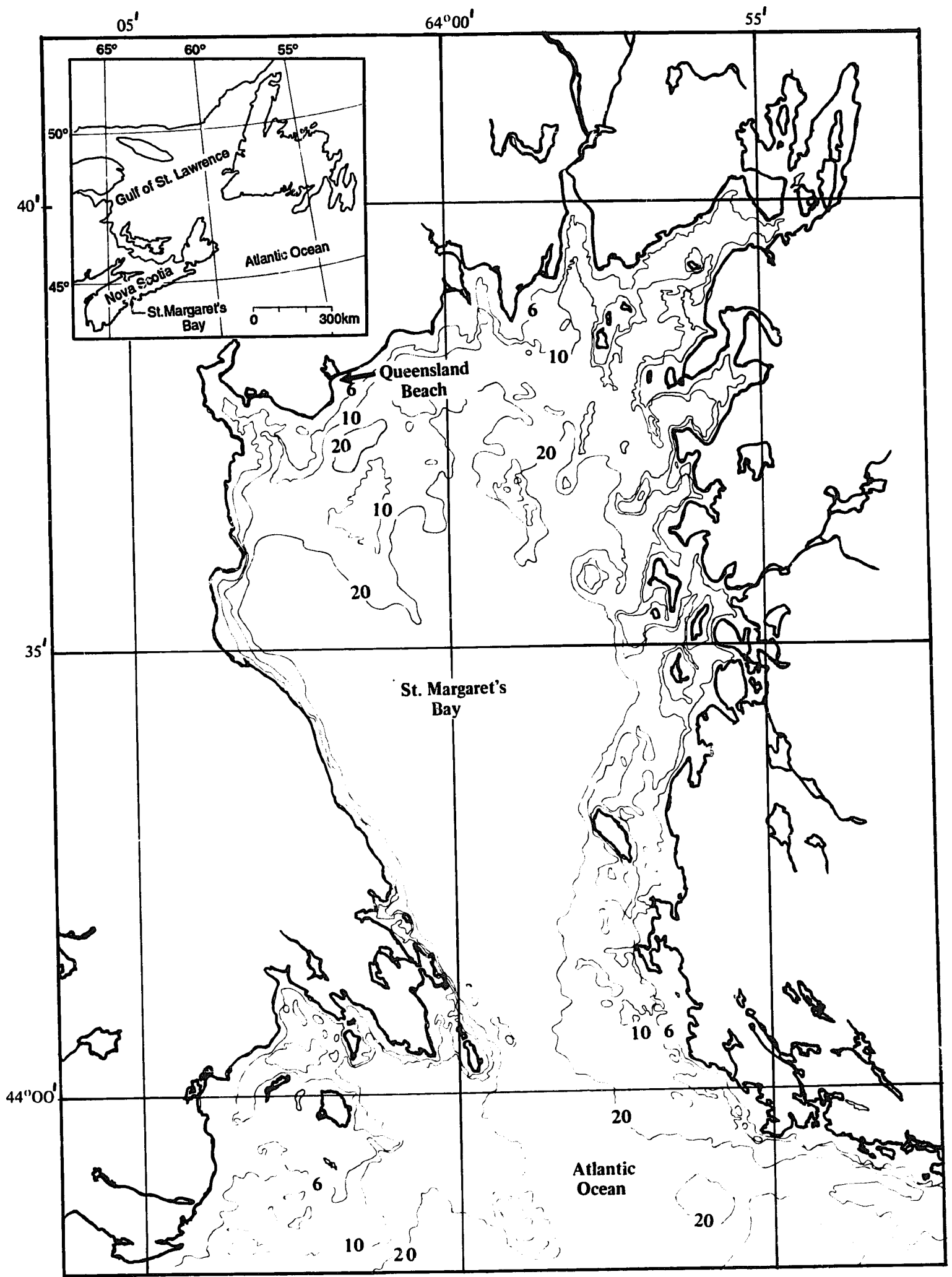

Fig. 1. Field site, Queensland Beach, St. Margaret's Bay, Nova Scotia, Canada. Note: contours in fathoms. 


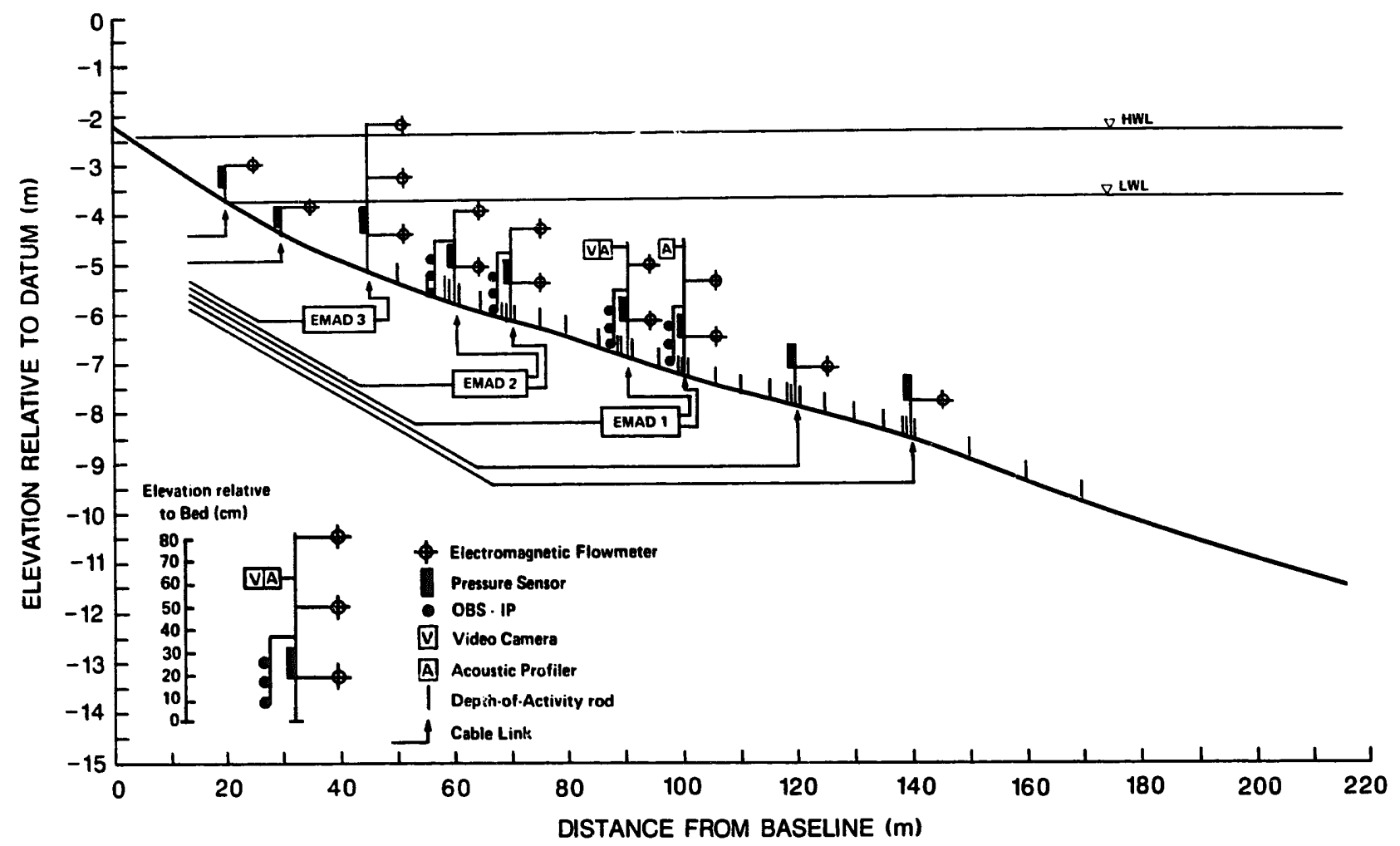

Fig. 2. Shoreface profile and sensor deployment. Note: EMAD 1-3 are underwater analogue-to-digital converters and digital transmission packages; they also distribute power to the sensors.

\section{Velocity}

The horizontal components of the shore-normal and shore-parallel velocity were measured with Marsh-McBirney Inc. biaxial electromagnetic current meters (Model OEM 512). These were calibrated by towing at a number of speeds in both the positive and negative directions; the gain was determined from a first-order, least squares regression of the sensor output. Zero offsets were checked in still water in the field both before and after deployment, as well as during calm conditions while deployed. Current records were also corrected for errors in gain and phase introduced by the output filter characteristics of the standard OEM 512 electronics (see Guza et al., 1988, and Doering, 1988 for discussion).

\section{Suspended sediment concentration}

High resolution time-series of suspended sediment concentration were obtained using optical backscatterance suspended solids sensors (OBS1P; Downing et al., 1981; Downing, 1983; D and
A Instruments and Engineering, 1988). Each OBS$1 \mathrm{P}$ sensor was calibrated in a sediment recirculating facility using sand from the respective field deployment locations. Linear correlations accounted for upwards of $95 \%$ (usually $>99 \%$ ) of the variance in the time-averaged analogue signal output over ranges of sediment concentration from 0.5 to 30 $\mathrm{g}^{-1}$ (Greenwood et al., 1990). Although the relative variance does not increase systematically with concentration for a given sensor, those sensors with higher gains appear to be more responsive to large magnitude short period fluctuations in concentration, even after calibration (Osborne, 1990). This implies a nonlinear response to "concentration fluctuations" even though time-averaged calibrations are linear; care was taken to collocate sensors with similar response characteristics. Preliminary results from laboratory and field crosscalibrations between the OBS-1P and a $2.25 \mathrm{MHZ}$ acoustic backscatter suspended sediment profiler hav reveciled signal responses that are temporally coherent and highly correlated (Greenwood et al., 
1990). This similarity in response to concentration fluctuations gives credibility to both sensors. The OBS-1P offset is, however, affected by backscatter from both organics and bubbles. Non-stationarity in the field offset prevented direct application of the laboratory offsets and therefore "clear water" offsets were determined from repetitive field measurements under calm conditions. The OBS-1P data were low-pass filtered in the frequency domain to remove high frequency noise $(1.5-2.0 \mathrm{~Hz})$ which appeared occasionally in the OBS signals (e.g. at the $60 \mathrm{~m}$ station) and to reduce the magnitude of large amplitude, short duration fluctuations (spikes) in some of the data which were uncorrelated with concentrations at other elevations. These "spikes" were often associated with the presence of organics in the water column (confirmed by video and diver observations). However, the filter also reduced the amplitudes of local, high frequency fluctuations in sediment concentration; such fluctuations are observed in calibration timeseries.

\section{Morphodynamics and sediment volume flux}

Large-scale changes in beach morphology to depths $<2 \mathrm{~m}$ were measured using either a level and staff or an OMNI Total Station. Survey lines were oriented normal to a baseline and spaced 15 $m$ apart to the north and south of the shorenormal sensor transect. A Raytheon Fathometer (Model DE719) was used to record shore-normal profiles extending offshore to approximately 400 $m$. The transducer position was fixed by triangulation and water depths were corrected for the transducer depth below water level; all survey points were reduced to a common benchmark at coordinates $\mathbf{0 , 0}$ on the survey grid.

Pre- and post-storm measurements from a grid of depth-of-activity rods provided greater resolution of morphological changes. The rods also provided measures of depth-of-activity, timeintegrated total (ITVF) and net (INVF) sediment volume flux, and were used to examine the balance of sediment in a shoreface control volume for individual storm events (Greenwood and Hale, 1980, p. 91, fig. 7.2; Greenwood, 1987, pp. 11241125 , figs. 4 and 5). The control volume was determined by taking the areal extent of the rod grid and multiplying by a arbitrary depth of 0.50 $\mathrm{m}$. The latter is a conservative depth for potential "re-activation". Depth-of-activity rods also indicate limits to the relative displacement of sensors above the bed during the storm (e.g. Greenwood and Sherman, 1988; Greenwood and Osborne, 1988).

\section{Sensor deployment}

Four sediment transport stations were located respectively $60,70,90$, and $100 \mathrm{~m}$ offshore from the baseline close to the upper limit of the foreshore. Each transport station (Fig. 2) consisted of: (1) a vertical array of 3 optical sensors (nominal elevations of $z \approx 0.08,0.18$ and $0.28 \mathrm{~m}$ ); (2) two current meters (nominal elevations of $z \approx 0.20$ and $0.50 \mathrm{~m}$ ); and (3) a pressure sensor (nominal elevation of $z \approx 0.20 \mathrm{~m}$ ). A vertical array of 3 current meters $(z \approx 0.20,0.50$ and $0.80 \mathrm{~m})$ and a pressure transducer $(z \approx 0.20 \mathrm{~m})$ were collocated $45 \mathrm{~m}$ offshore, and individual current meters $(z \approx 0.20 \mathrm{~m})$ and pressure transducers $(z \approx 0.20 \mathrm{~m})$ were collocated at 20, 30, 120 and $140 \mathrm{~m}$ offshore (Fig. 2).

An underwaier video camera was deployed at the $90 \mathrm{~m}$ station to record bedforms and sediment re-suspension on a semi-continuous basis during daylight hours. Sinilar observations were made at the remaining stations by SCUBA divers whenever conditions permitted.

\section{Data acquisition and analytical techniques}

All electronic sensors were hardwired to analogue-to-digital conversion and transmission packages (EMAD, Fig. 2). During transport events, output signals were recorded at $4 \mathrm{~Hz}$ essentially continuously, being interrupted for one minute after every 29 for data control purposes only. Data were stored directly to magnetic tape, allowing monitoring to proceed continuously for up to 8 hours. A complete description of the computercontrolled data acquisition system and underwater digitization and transmission system is given by Hazen et al. (1987). Sensor outputs were converted from voltages to appropriate units using the offset and gain characteristic of each sensor.

Time-series were truncated to approximately seventeen minutes of record to ensure stationarity in this rapidly changing environment, while at the 
same time retaining a sufficient number of points (4096) to maintain a high degree of statistical confidence, especially with respect to the fast Fourier transforms. Statistical descriptions of the nearshore velocity and suspended sediment concentration fields and the water-surface elevation (mean, standard deviation and skewness) were computed using the BMDP 2D Statistical Analysis Program (Dixon, 1985). Average and maximum values of both wave height and oscillatory current speed were estimated from the standard deviation of water surface elevation and velocity records respectively using the accepted conventions. Variance spectra, cross-spectra and cross-correlations were computed using the BMDP 1T and 2T Time Series Analysis Programs (Dixon, 1985). The data were demeaned using standard BMDP 1T preprocessing routines and spectral estimates were obtained every $0.01 \mathrm{~Hz}$ from 0.0 to $2.0 \mathrm{~Hz}$ witit a resolution bandwidth of $0.03 \mathrm{~Hz}$ and 70 degrees of freedom.

\section{Sediment transport calculations}

The product of the instantaneous sediment concentration and velocity measured at a point gives the local instantaneous sediment transport rate, uc. The time-average of the instantaneous products gives the local net sediment transport rate:

$<u c>_{\text {net }}=\frac{1}{n} \sum u c$

where $n=$ the sample size. Assuming that the concentration and velocity at any instant in time are composed of a steady component (overbar) and an unsteady or fluctuating (') component, then:

$c=\bar{c}+c^{\prime}$

$u=\bar{u}+u^{\prime}$

and the local net sediment transport rate, $\langle u c\rangle$, may also be given by:

$$
\begin{aligned}
& \langle u c\rangle=\left\langle\left(\bar{u}+u^{\prime}\right)\left(\bar{c}+c^{\prime}\right)\right\rangle \\
& =\bar{u} \bar{c}+\left\langle\bar{u} c^{\prime}\right\rangle+\left\langle\bar{u}^{\prime} c\right\rangle+\left\langle u^{\prime} c^{\prime}\right\rangle
\end{aligned}
$$

The terms $\left\langle\bar{u} c^{\prime}\right\rangle$ and $\left\langle u^{\prime} \bar{c}\right\rangle$ go to zero because by definition the time-average of the fluctuations is zero. Thus:

$$
\langle u c\rangle=\bar{u} \bar{c}+\left\langle u^{\prime} c^{\prime}\right\rangle
$$

The term $\bar{u} \bar{c}$ is called the local mean sediment transport rate, computed as the time-averaged velocity multiplied by the time-averaged concentration. The term $\left\langle u^{\prime} c^{\prime}\right\rangle$ is a measure of the correlation between fluctuations in concentration and velocity (termed "flux coupling" by Jaffe et al., 1985). Low values of this term indicate that fluctuations in concentration relative to fluctuations in velocity are random; large values indicate a large degree of temporal correlation. Jaffe et al. (1985) have already demonstrated that this term is typically non-zero in the surf zone. While this fluctuating component of sediment transport may be computed by taking the product of residuals about the mean for both concentration and velocity, a more convenient way uses cross-spectral analysis (e.g. Huntley and Hanes, 1987). Additionally, the co-spectrum gives the cross-product between concentration and velocity as a function of frequency; this reveals the relative contributions to the rate and direction of sediment transport of oscillations at different frequencies. Integration of the co-spectrum over all frequencies and division by the number of frequency bands gives the local net oscillatory sediment transport rate, which is equivalent to the "flux coupling" term introduced by Jaffe et al. (1985).

It is obvious from the physical size of the current and sediment concentration sensors that they cannot be perfectly collocated in space; furthermore, there are greater limitations on the electromagnetic flowmeter with respect to its proximity to the bed. A number of theories exist which could be used to predict the form of the time-averaged velocity profile (e.g. Grant and Madsen, 1979); however, given the large uncertainties in the bed roughness and the effects of wave, current and suspended sediment interactions under breaking waves, it seems more useful to discuss the results assuming a uniform current profile, and only later to examine their sensitivity to various forms of the velocity profile. In this research a first approximation to the computation of suspended sediment flux rates is made by using cross-products of the concentrations measured at each of the OBS-1P elevations 
$(z \approx 0.08,0.18$, and $0.28 \mathrm{~m})$ and local velocities measured at the lowest current sensor elevation $(z \approx 0.20 \mathrm{~m})$. When a uniform velocity profile is assumed, the vertical structure of the mean sediment transport for example, simply reflects the vertical variation of time-averaged concentrations and the magnitude and direction of the mean flow.

\section{Storm event summary}

The storm event described in this paper occurred on October 25/26, 1987 and lasted for approximately $18 \mathrm{~h}$ over a complete spring tidal cycle; Figure 3 illustrates the temporal variation in wind, waves, tide and wave-induced currents. Significant wave heights $\left(H_{\mathrm{s}}\right)$ increased and decreased coincident with the wind; the peak period $\left(T_{\mathrm{pk}}\right)$ however, shows a gradual increase throughout the event as energy shifted from wind-forced waves to swell. The peak of the storm coincided with low tide and wave heights exceeded $2 \mathrm{~m}$ at breaking with a peak period of $8 \mathrm{~s}$. Maximum orbital speeds $\left(u_{\mathrm{s}}\right)$ reached $1.58 \mathrm{~m} \mathrm{~s}^{-1}$ and cross-shore mean currents $(\bar{u})$ reached $0.20 \mathrm{~m} \mathrm{~s}^{-1}$ at the storm peak in the inner surf zone. Maxima in orbital speeds, onshore velocity skewness $\left(u_{\text {sk }}\right)$ and offshore mean flow (Fig. 3) coincided with both the maximum incident wave and low tide ( $p$-minimum depth) at approximately $1500 \mathrm{~h}$ on October 25 , when wind speed reached 20 knots $\left(10.3 \mathrm{~m} \mathrm{~s}^{-1}\right)$. Wind speed peaked for a short time at 35 knots $\left(18.0 \mathrm{~m} \mathrm{~s}^{-1}\right)$ at approximately $1800 \mathrm{~h}$ on the same day during a rising tide; a second (smaller) peak in orbital speeds occurred at this time. During the storm maximum, breaking waves extended $60-70 \mathrm{~m}$ offshore, causing damage to both stations at these locations. Owing to the steepness of the nearshore slope, however, the surf zone was confined within $45 \mathrm{~m}$ of the shoreline for much of the storm.

Figure 4 illustrates the temporal and spatial variation in both the near-bed $(z \approx 0.20 \mathrm{~m})$ oscillatory velocities $\left(u_{\mathrm{s}}\right)$ and the mean sediment concentrations $(\bar{c} ; z \approx 0.08 \mathrm{~m})$ across the shoreface throughout the storm cycle. Orbital speeds followed a coherent pattern increasing and decreasing in phase with the storm waves as they increased in height and then decayed. Speeds were clearly depth dependent, increasing landwards from the
$100 \mathrm{~m}$ station. The pattern of mean sediment concentrations $(\bar{c})$ was less coherent both spatially and temporally, as might have been expected; however, increases and decreases in concentration did occur as orbital speeds increased and decreased. Unfortunately, with the exception of the $100 \mathrm{~m}$ station, the optical sensors at all other stations were contaminated by organics for the period 1500-1800 $\mathrm{h}$ inclusive, thus limiting interpretations to the period of the storm buildup and decay. Sediment concentrations recorded at the $100 \mathrm{~m}$ station however, indicated mean values increasing to a maximum of $2.6 \mathrm{~g} \mathrm{l}^{-1}$ between 1500 and $1600 \mathrm{~h}$ and then decreasing in phase with the near-bed orbital speeds.

\section{Wave-induced suspended sediment transport}

It is evident from previous studies that the magnitude and the direction of suspended sediment transport depends directly upon the form of the surface gravity waves and thus the character of the near-bed velocity field. Changes in surface gravity wave form occur through shoaling; a useful first approach to the examination of sediment transport is therefore to consider it in relation to changes that occur in the wave height-to-water depth ratio at a given location. Furthermore, shifts in the flow regime (Simons and Richardson, 1962, 1966; Sherman and Greenwood, 1984; Greenwood and Sherman, 1986, 1988; Ollerhead and Greenwood, 1990) associated with the bedform response to increases or decreases in bed shear will also affect the direction and magnitude of the sediment transport (Inman and Bowen, 1963; Sleath, 1982). The magnitude of sediment concentration at any elevation, its rate of change and the phase relationships between concentration and fluid velocity have been shown to be strongly influenced by the height and spacing (steepness) of bedforms (Osborne and Greenwood, 1992).

\section{Non-breaking waves $\left(0.1<H_{\mathrm{s}} / h<0.2\right)$}

Figure 5a illustrates cross-shore velocity and sediment concentration spectra and the corresponding co-spectra obtained from the $70 \mathrm{~m}$ station under shoaling waves. Wave-induced kinetic 

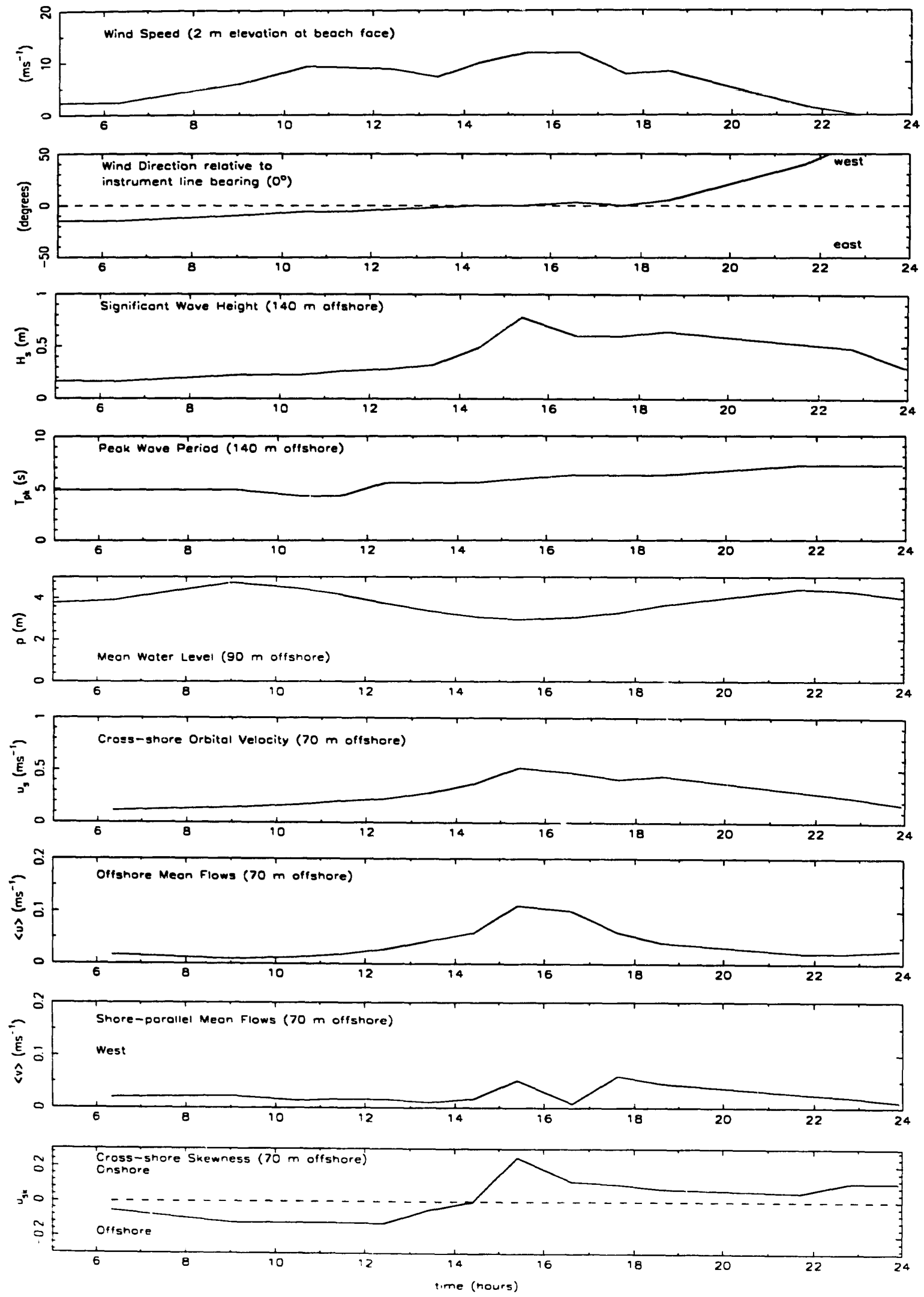

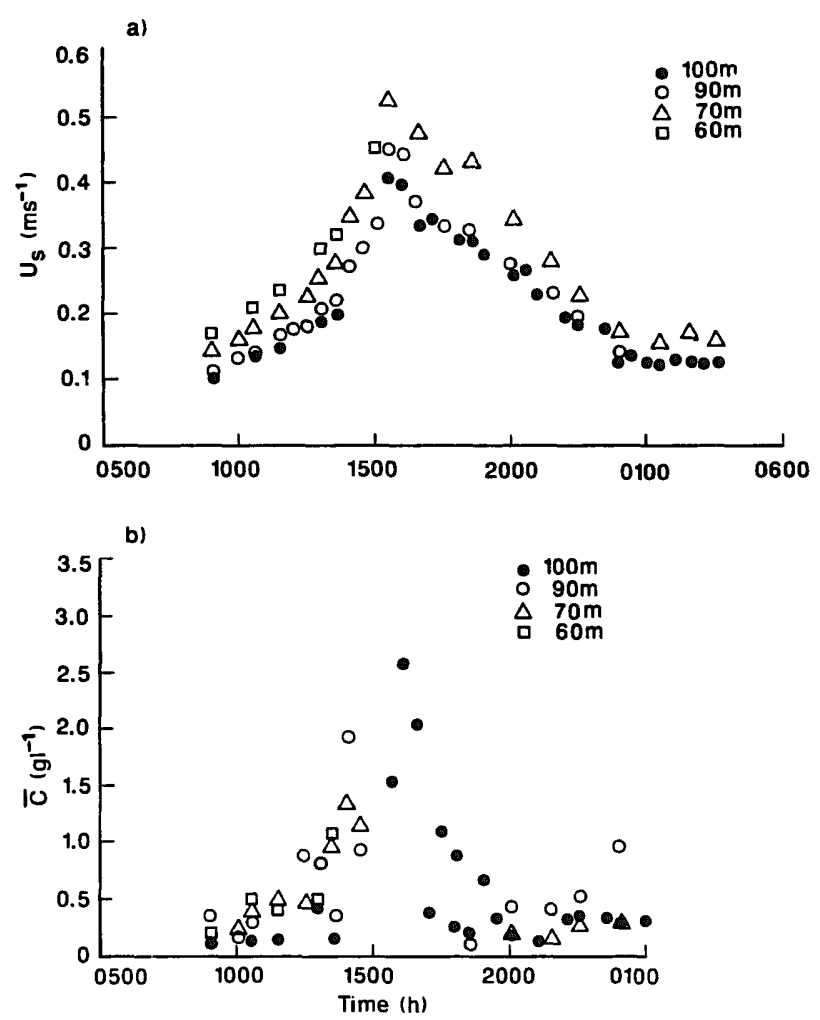

Fig. 4. Temporal and spatial variability of: (a) near-bed orbital speeds $(z \approx 0.20 \mathrm{~m})$; (b) time-averaged sediment concentrations $(z \approx 0.08 \mathrm{~m})$. Note: concentrations recorded at the storm peak from the 60,70 and $90 \mathrm{~m}$ stations were contaminated and are not plotted; velocities from the $60 \mathrm{~m}$ station were not available after $1500 \mathrm{~h}$.

energy is spread across a wide frequency band, but the peak of the velocity spectrum occurs at $0.33 \mathrm{~Hz}(3 \mathrm{~s})$ corresponding to the wind-driven incident waves. A minor, but statistically signifcant, spectral peak occurs at $0.125 \mathrm{~Hz}(8 \mathrm{~s})$ corresponding to long period swell which was present prior to the wind-wave growth. Another minor peak occurs near the wind-wave harmonic at $0.75 \mathrm{~Hz}(1.3 \mathrm{~s})$. In contrast, most of the variance in the concentration spectrum occurs at frequencies less than $0.1 \mathrm{~Hz}(10 \mathrm{~s})$. There are no significant peaks in the concentration spectrum corresponding to either the wind-wave frequency $(0.20-0.40 \mathrm{~Hz})$ or the wind-wave harmonic $(0.75 \mathrm{~Hz})$ as might have been expected if sediment concentrations were responding to individual incident waves. These do occur under some conditions, however, as shown by Greenwood et al. (1990).

The co-spectrum from the $0.08 \mathrm{~m}$ elevation exhibits peaks which correspond to both the wind wave and swell frequencies in the cross-shore velocity spectrum. In this example, the larger positive spectral densities coincident with the wind wave frequencies $(0.20-0.40 \mathrm{~Hz})$ indicate a larger onshore transport of sediment by the wind waves thaii by the swell. The smaller but distinct negative spectral peak at frequencies $<0.05 \mathrm{~Hz}$ indicates that offshore transport of suspended sediment is associated with low frequency waves. The cospectrum from each elevation reveals that no significant suspended sediment transport was occurring at frequencies greater than $0.5 \mathrm{~Hz}(2 \mathrm{~s})$; this reflects the low velocity variance at frequencies greater than $0.5 \mathrm{~Hz}$ and the obvious lack of correlation between concentration fluctuations and velocity fluctuations at these frequencies. Furthermore, they reveal the rapid decrease in transport with elevation at all frequencies. Under shoaling waves oscillatory transport of suspended sediment was restricted to within short distances of the bed and dominated by an onshore flux at wind-wave frequencies $(0.20$ to $0.4 \mathrm{~Hz})$; a distinct, but much smaller offshore transport occurred at low frequencies $(<0.05 \mathrm{~Hz})$.

\section{Occasionally spilling breakers $\left(H_{\mathrm{s}} / h>0.2\right)$}

As waves increased in size and began to break, the nature of the sediment transport as revealed in the structure of the co-spectra varied considerably. For example, Fig. 5b illustrates the velocity and concentration spectra together with associated co-spectra from the $70 \mathrm{~m}$ station when the wave height-to-water depth ratio had increased to approximately 0.2 and waves were spilling occasionally. An order of magnitude increase in sediment concentrations occurred at all frequencies under these conditions, but once again little or no

Fig. 3. Temporal variability of: wind speed and direction at the beach face; significant wave height $\left(H_{\mathrm{s}}\right)$ and peak wave period $\left(T_{\mathrm{pk}}\right)$ at the $140 \mathrm{~m}$ station; mean water level $(p)$ at the $90 \mathrm{~m}$ station; average orbital current speed $\left(u_{\mathrm{s}}\right)$, cross-shore and alongshore mean flows $(\langle u\rangle,\langle v\rangle)$ and cross-shore velocity skewness $\left(u_{\text {sk }}\right)$ at the $70 \mathrm{~m}$ station. 
a)
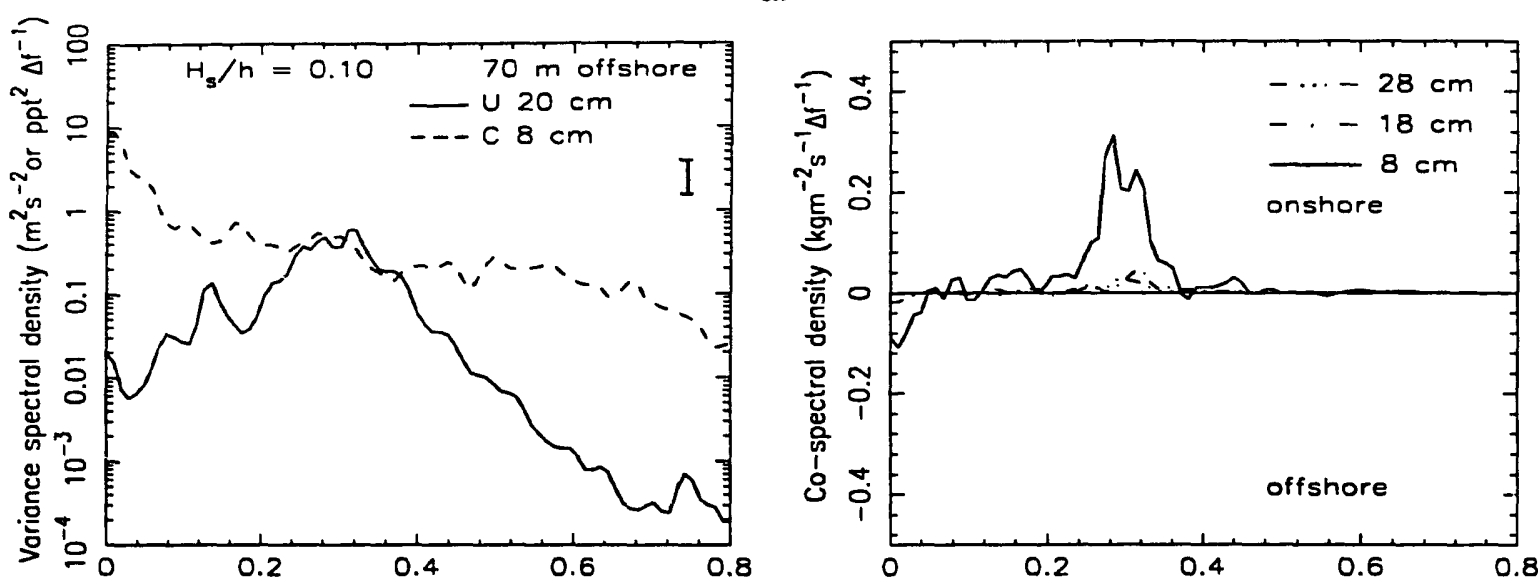

b)
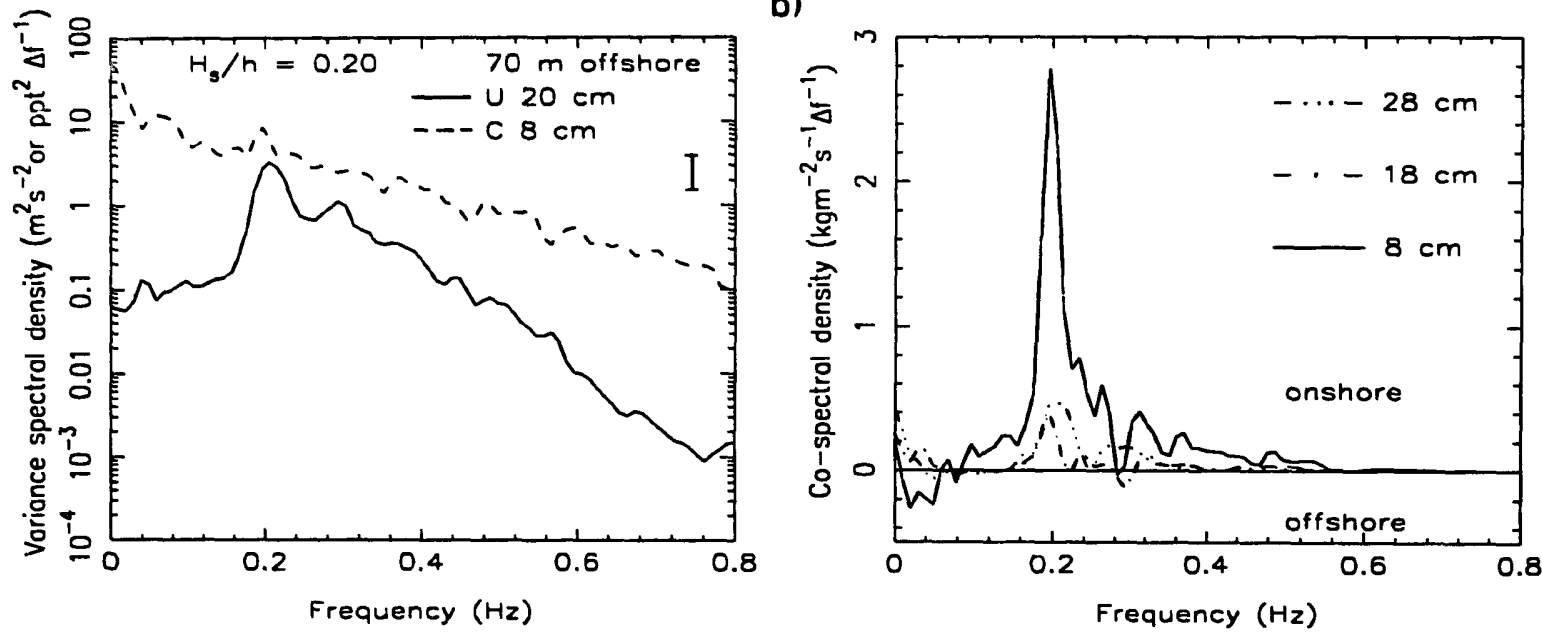

Fig. 5. Cross-shore velocity $(u)$ and concentration $(c)$ spectra and co-spectra (70 $\mathrm{m}$ station) typical of storm-wave growth: (a) shoaling waves; (b) breaking waves (spilling breakers). Note: the error bar indicates the $95 \%$ confidence limits for the spectral estimates.

structure appeared in the spectrum. It is readily apparent that the relative magnitude of the transport associated with the wind waves had increased significantly from that under non-breaking conditions (cf. Fig. 5b with Fig. 5a). Under these nearbreaking conditions, the co-spectra from the 0.18 and $0.28 \mathrm{~m}$ elevations indicate onshore transport at wind wave frequencies of a magnitude similar to those from much lower elevations $(0.08 \mathrm{~m})$ under non-breaking conditions. The co-spectra in Fig. 5b also indicate that the transport of suspended sediment attributable to low frequencies also increased substantially; this long wave transport was now equal in magnitude to that attributable to wind waves earlier in the storm. However, in contrast to the suspended load under shoaling waves, not all of the transport attributable to low frequencies was directed offshore; positive peaks between 0.05 and $0.10 \mathrm{~Hz}$ appear in both cospectra from higher elevations $(z \approx 0.18$ and $0.28 \mathrm{~m}$ ) indicating onshore transport at these heights above the bed. This reversal of the transport direction higher in the flow reflects important temporal and spatial interdependencies between the sediment concentration and horizontal velocity. It emphasizes the importance of phase lags introduced by the finite time necessary for sediment re-suspension at the bed and its transfer upwards into the flow (Greenwood et al., 1990, 199la; Osborne and Greenwood, 1992).

The spectra and co-spectra observed under breaking incident waves indicate an increase in the 
effectiveness of both wind waves and low frequency waves to transport sediment in suspension. The increase in onshore transport at wind wave frequencies correlates well with the increase in velocity skewness (Fig. 3) observed under the highly non-linear breaking waves. The increase in offshore transport at low frequencies is restricted close to the bed $(0.08 \mathrm{~m})$ and reflects the strong coupling between the offshore phases of long waves and large sediment concentrations in the water column; this is associated with groupiness in the incident waves and the presence of a forced long wave (Fig. 6-see also Greenwood and Osborne, 1992; Osborne and Greenwood, 1992).

\section{Spatial dependency of wave-induced suspended sediment transport}

The time-series illustrated in Fig. 7 reveal changes in both the cross-shore velocity and suspended sediment concentration across the shoreface under shoaling waves. The $H_{\mathrm{s}} / h$ ratio associated with these time-series increased from 0.07 at the $100 \mathrm{~m}$ station to 0.14 at the $60 \mathrm{~m}$ station. It is readily apparent that sediment concentrations respond to both individual waves and, more importantly, to wave groups. Sediment resuspension as a wave group passes involves a cumulative increase and then decrease in concen- tration at any given elevation, which may last for several tens of seconds; fluctuations associated with individual wave cycles are superimposed. Spatially coherent suspension events can be clearly identified from one location to the next as groups of large waves propagate across the shoreface (Fig. 7). Spatial coherence is confirmed by crosscorrelations between both velocity and concentration measurements at each of the stations across shore (Fig. 8; Table 2). The time lags associated

TABLE 2

Time lags between stations

\begin{tabular}{lrrrrrr}
\hline Stations & $100-90$ & $100-70$ & $100-60$ & $90-70$ & $90-60$ & $70-60$ \\
\hline$d x$ & 10.0 & 30.0 & 40.0 & 20.0 & 30.0 & 10.0 \\
$d h$ & 0.3 & 0.5 & 1.2 & 0.2 & 0.9 & 0.7 \\
$C$ & 6.6 & 6.5 & 6.2 & 6.4 & 6.1 & 6.0 \\
$t$ & 1.5 & 4.6 & 6.4 & 3.1 & 4.9 & 7.1 \\
$R_{\max -u}$ & 2.0 & 5.5 & 7.5 & 3.5 & 5.75 & 2.3 \\
$R_{\max -c}$ & 1.8 & 6.3 & 7.5 & 4,3 & 6.0 & 2.3 \\
\hline
\end{tabular}

$d x=$ separation distance between stations $(\mathrm{m})$;

$d h=$ change in water depth between stations (m);

$c=$ average phase velocity between stations $\left(\mathrm{m} \mathrm{s}^{-1}\right)$

$=1 / N \sum\left(g h_{\mathrm{i}}\right)^{0.5}$, where $h_{\mathrm{i}}=$ local depth $(\mathrm{m}), N=$ number of depth increments between stations spaced $1 \mathrm{~m}$ apart; $t=C \cdot d x=$ times of travel between stations (s);

$R_{\max -u}=$ lag of maximum correlation for velocity data (s); and $R_{\max -\mathrm{c}}=$ lag of maximum correlation for concentration data (s).
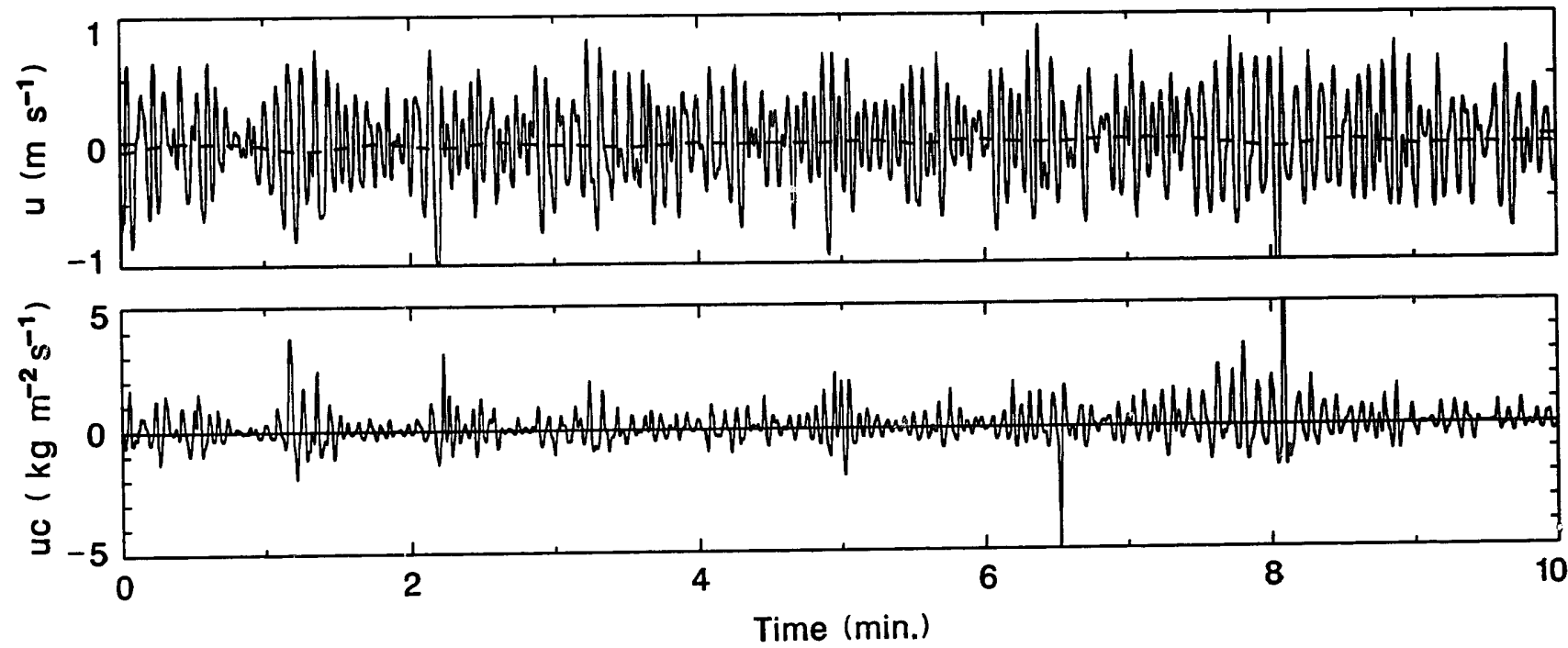

Fig. 6. Time-series of cross-shore velocity $(u: z \approx 0.20 \mathrm{~m})$ and suspended sediment transport (uc) from the $70 \mathrm{~m}$ station during stormwave growth $\left(1354 \mathrm{~h} ; H_{\mathrm{s}} / \boldsymbol{h}=0.2\right)$; concentrations from $\left.z \approx 0.08 \mathrm{~m}\right)$. Note: instantaneous velocity denoted by a solid line and lowpass filtered series by a dashed line: bandwidth for the low pass filter was $0.1 \mathrm{~Hz}$ and the filter bandwidth $(-3 \mathrm{db})$ was $0.025 \mathrm{~Hz}$. 

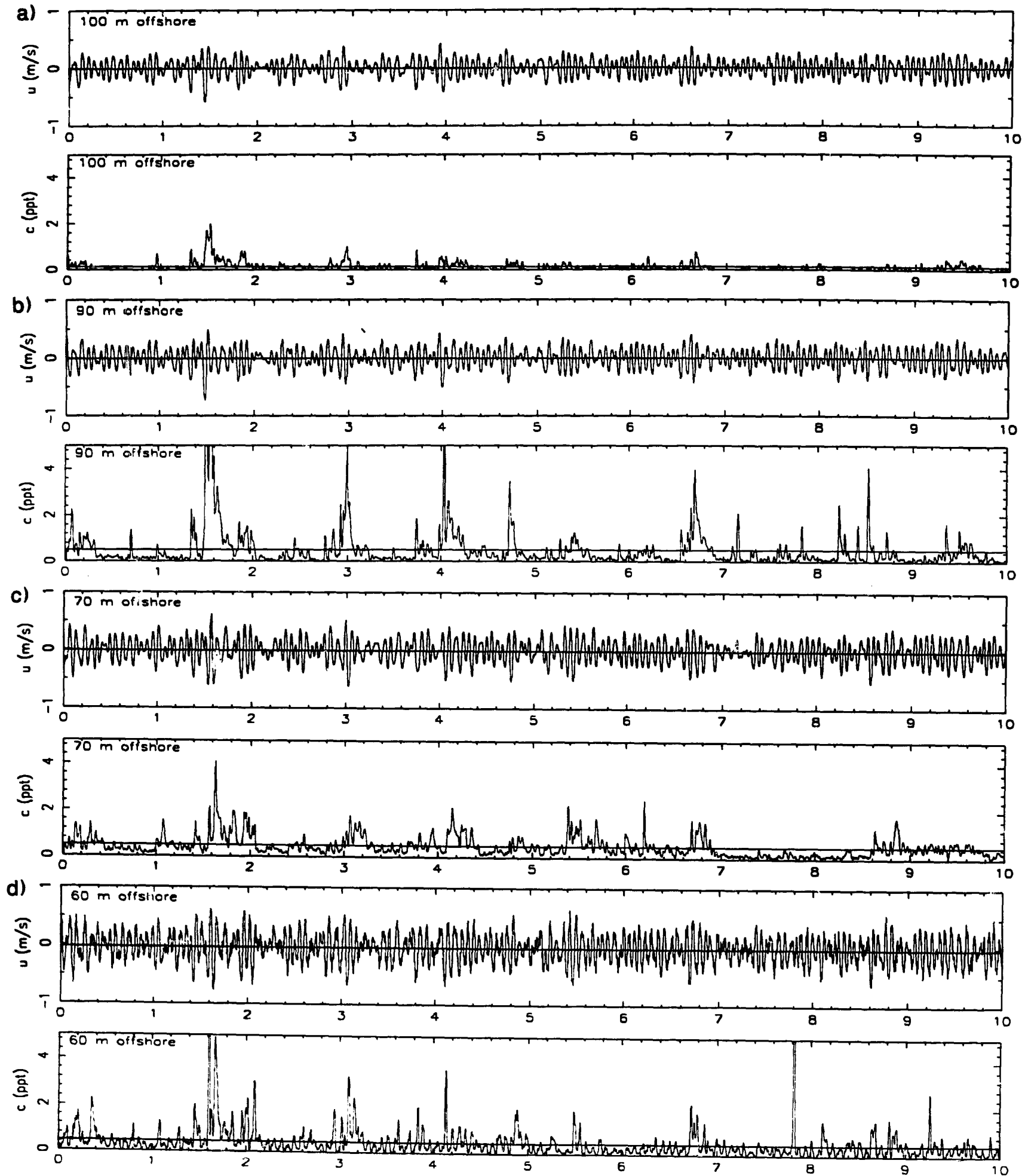

Time (min.)

Fig. 7. Time series of cross-shore velocity $(u ;: \approx 0.20 \mathrm{~m})$ and suspended sediment concentration $(c ; z \approx 0.08 \mathrm{~m})$ from Queensland Beach (87:10:25:11:24): (a) $100 \mathrm{~m}$ station, $H_{\mathrm{s}} / h=0.07$; (b) $90 \mathrm{~m}$ station, $H_{\mathrm{s}} / h=0.08$; (c) $70 \mathrm{~m}$ station, $H_{\mathrm{s}} / h=0.09 ;$ (d) $60 \mathrm{~m}$ station,
$H_{\mathrm{s}} / h=0.14$. 


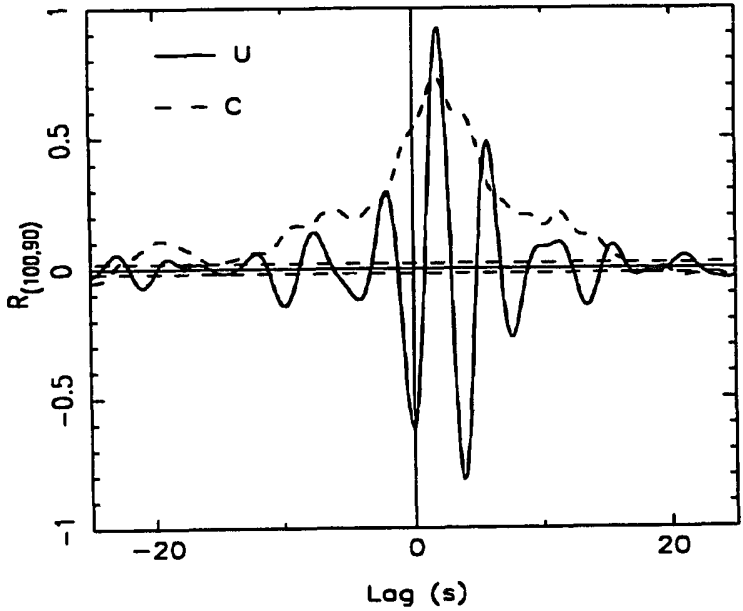

Fig. 8. Cross-correlations between cross-shore velocities $(u$; $z \approx 0.20 \mathrm{~m}$ ) and between suspended sediment concentrations $(c ;$ $z \approx 0.08 \mathrm{~m}$; measured at the $100 \mathrm{~m}$ and $90 \mathrm{~m}$ stations, respectively, Queensland Beach (87:10:25:11:24). Note: horizontal dashed lines denote $95 \%$ confidence intervals.

with the maximum positive correlations compare well with the time lag for wave groups travelling between stations computed using depth-dependent phase velocities based upon shallow water linear wave theory (Table 2).

In general, sediment concentrations tend to increase shoreward, as expected with increasing wave height-to-water depth ratios. The concentrations recorded at $90 \mathrm{~m}$, however, appear somewhat larger than might be expected by the trend. This can be attributed, at least in part, to the increased sensitivity of the sensors deployed at this location to rapid fluctuations in concentration as noted earlier; however, it is not possible to totally eliminate the possibility of shifts in the relative vertical positions of adjacent sensor arrays as a result of local erosion and/or accretion.

The effects of wave shoaling are evident in the increasingly peaked crests and flattened troughs (resulting from wave skewness) and the increasing saw-toothed shape (resulting from wave asymmetry) revealed in the sequence of velocity time-series from the $100 \mathrm{~m}$ station to the $60 \mathrm{~m}$ station (Fig. 7). These effects are also reflected in the dramatic increase in net onshore transport; compare the cospectrum from the $60 \mathrm{~m}$ station relative to those at the 70, 90 and $100 \mathrm{~m}$ stations (Fig. 9). The onshore sediment transport rate at $60 \mathrm{~m}$, for example, is of the order of twice that at 70 and
$90 \mathrm{~m}$. Examination of the spatial variability in the cross-shore velocity spectra (Fig. 9) indicates that the relative distribution of energy across frequency space does not change a great deal up to the point of wave breaking on this non-barred beach. There is, however, an overall increase in energy density towards shore as expected, and a slight shift of wind-wave energy towards both higher and lower frequencies. In general, the spatial pattern of sediment flux reflects increasing wave transformation landward, resulting in a shoreward increase in onshore transport at wind-wave frequencies.

\section{Suspended sediment transport by time-averaged cross-shore currents}

Visual observations indicated that rip currents (spaced approximately $20 \mathrm{~m}$ apart) were present in the inner surf zone by $1230 \mathrm{~h}$ on October 25 , and these persisted throughout the storm peak. Large rips were clearly visible during a falling tide between 1400 and $1500 \mathrm{~h}$, while somewhat smaller rip currents developed during the next low tide (0200-0600 h on October 26). However, it is unlikely that the rip currents extended any significant distance seaward of the fully saturated surf zone, which was in general restricted to within $45 \mathrm{~m}$ of the shoreline at all times. Nevertheless, time-averaged, mean cross-shore currents of relatively large magnitude were recorded well outside this zone (Fig. 10) and therefore could not be attributable to a rip current origin. These timeaveraged currents measured close to the bed $(0.20$ m elevation) at the 45, 70,90 and $100 \mathrm{~m}$ stations were all directed offshore throughout the storm, reaching a maximum of $0.20 \mathrm{~m} \mathrm{~s}^{-1}$ at the shallowest station. In general, these currents decreased in magnitude offshore and were less than $0.10 \mathrm{~m} \mathrm{~s}^{-1}$ seaward of $60 \mathrm{~m}$, except during the storm peak, when speeds reached $0.12 \mathrm{~m} \mathrm{~s}^{-1}$ at both $70 \mathrm{~m}$ and $90 \mathrm{~m}$. The largest offshore mean current speeds coincided temporally with the peak in orbital speeds $\left(u_{\mathrm{s}}\right)$ and also with the minimum water depths, the latter associated with a low tide at $1500 \mathrm{~h}$, October 25 . In general, the mean currents exhibited a small increase in magnitude with elevation between 0.2 and $0.5 \mathrm{~m}$ above the bed (Fig. 10); however, at the $45 \mathrm{~m}$ station, where a tri-level 

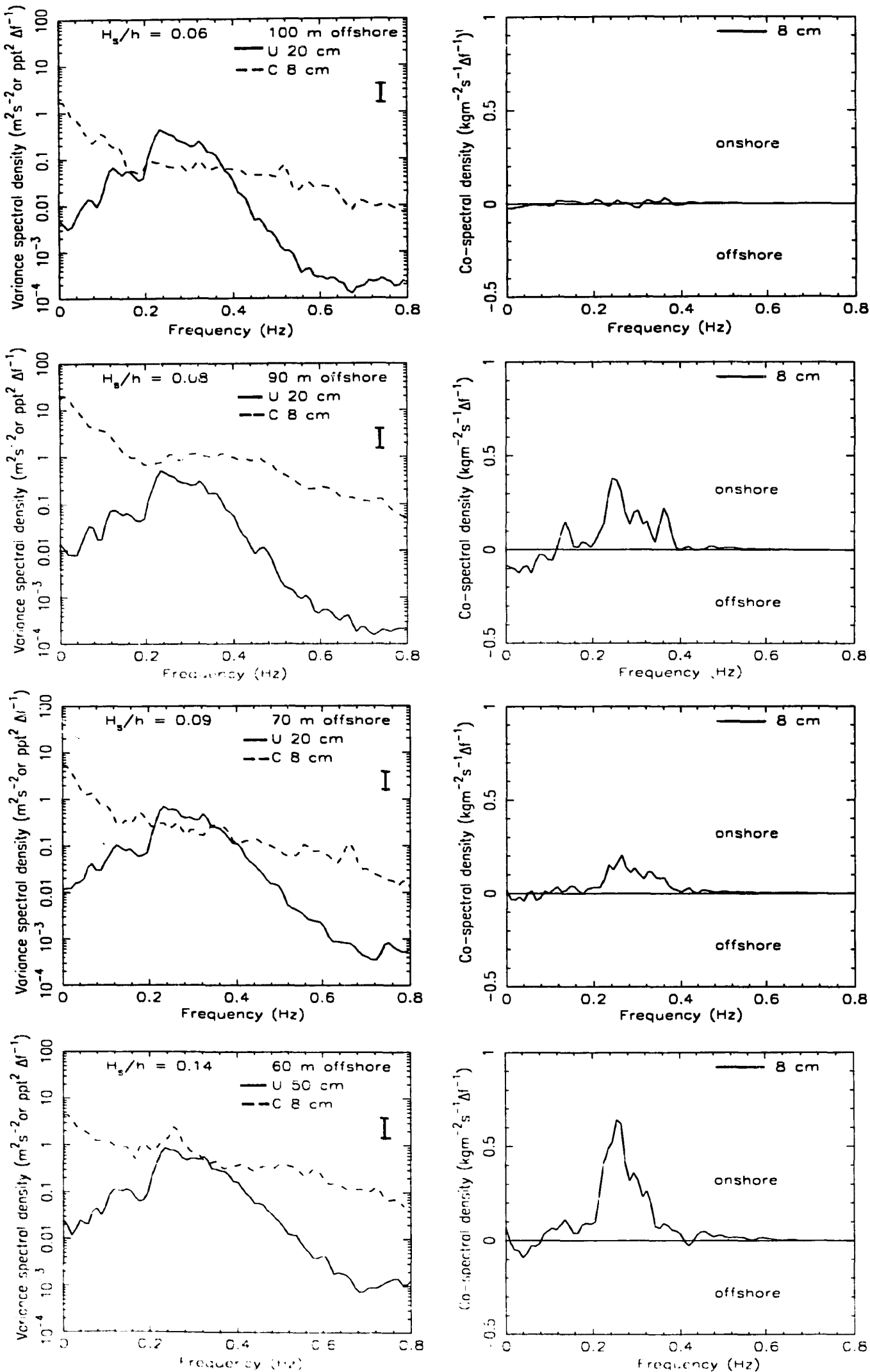

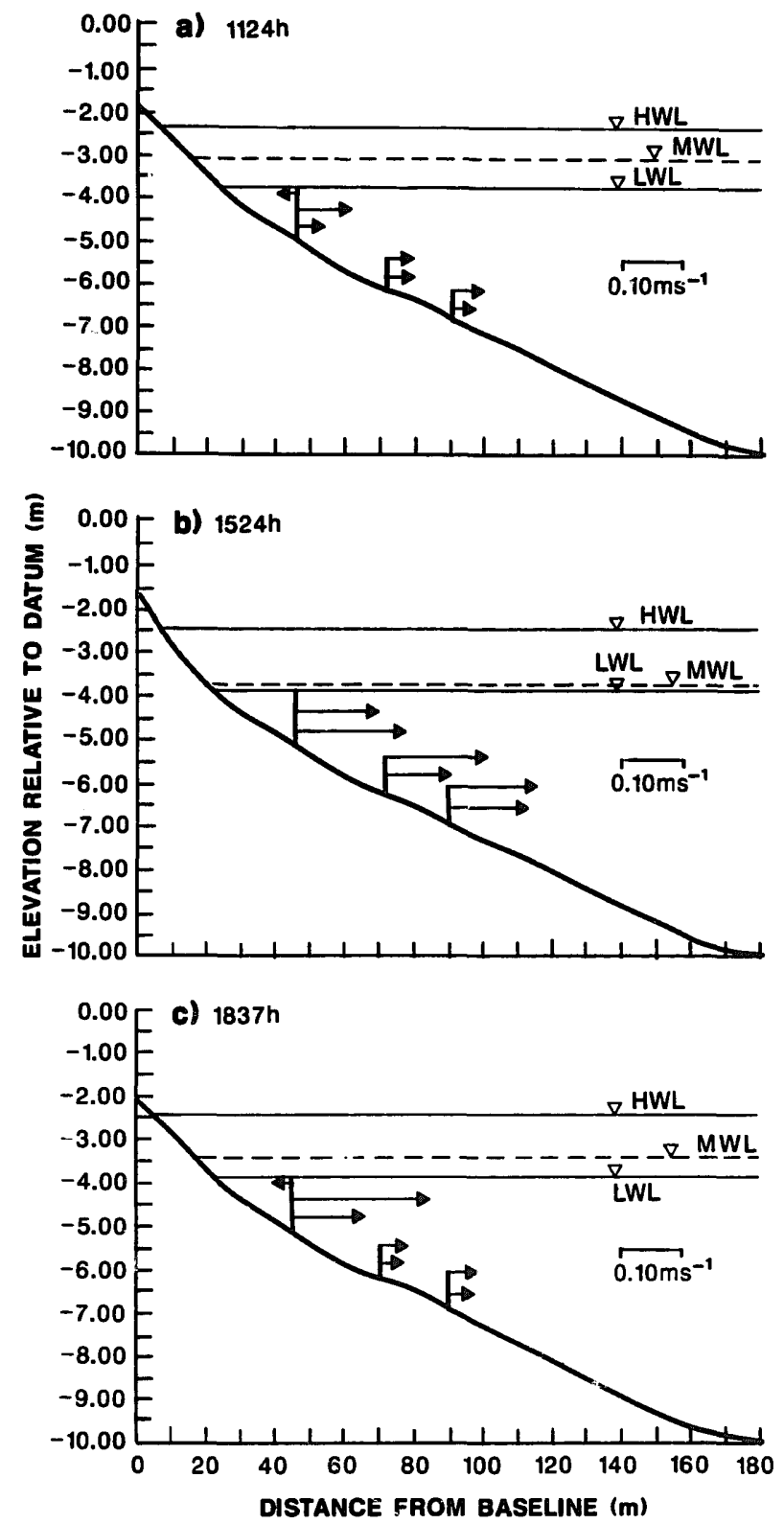

Fig. 10. Temporal and spatial variabiliiy in the vertical structure of the time-averaged (mean) cross-shore currents throughout the storm peak at Queensland Beach: (a) $1124 \mathrm{~h}$; (b) $1524 \mathrm{~h}$; (c) $1836 \mathrm{~h}$. Note: arrows are scaled cross-shore current vectors.

array of current meters was deployed, the upper sensor ( $0.8 \mathrm{~m}$ elevation) exhibited onshore mean flows, while mean flows measured by the lower sensors (at $0.5 \mathrm{~m}$ and $0.2 \mathrm{~m}$ elevation) were directed offshore throughout the storm

(Fig. 10a,c). This vertical stratificacion at $45 \mathrm{~m}$ reflects the landward translation of water in the upper water column due to the presence of breaking waves and an offshore current closer to the bed required to balance the shoreward mass and momentum flux at the surface. This mean flow structure is typical of a pressure gradient driven "undertow" resulting from a mean water level setup in the inner surf zone (e.g. Greenwood and Osborne, 1990a; Osborne and Greenwood, 1991); the details of the set-up driven flow at Queensland Beach are not presented in this paper.

Vertical variations in the magnitude of the timeaveraged sediment concentrations are illustrated in Fig. 11, which documents conditions during the storm growth, as both the near-bed orbital velocity and wave height-to-water depth ratios gradually increased. The vertical distribution of the timeaveraged sediment concentration follows a nonlinear decay with elevation; although only three data points are available, such a pattern supports the large number of earlier laboratory and field observations of an exponential decay function for time-averaged sediment suspensions under waves (e.g. Kennedy and Locher, 1972; Nielsen et al., 1982; Jaffe et al., 1985; Skafel and Krishnappan, 1984; Sternberg et al., 1984, and others). Furthermore, the mean concentrations increased consistently during the storm-wave growth coincident with increases in both the oscillatory and mean currents. Thus the mean suspended sediment transport rate also increased over time up to the storm peak; however, this transport was constrained by local patterns of the vertical distribution of both the mean current and the mean suspended sediment concentration.

Cross-shore orbital speeds near the bed were largest at a water depth of approximately $2.75 \mathrm{~m}$ and decreased monotonically with increasing depth throughout the storm peak (Fig. 12). In shallower water $(0.5$ to $2 \mathrm{~m})$, the orbital speeds were 50 to $75 \%$ lower than the maximum, but also exhibited a similar depth dependence. The time-averaged

Fig. 9. Spatial variability of cross-shore velocity $(u ; z \approx 0.20 \mathrm{~m})$ and sediment concentration $(c ; z \approx 0.08 \mathrm{~m})$ spectra and associated co-spectra at Queensland Beach during storm-wave growth (87:10:25:11:24). Note: station locations and wave height-to-water depth ratios $\left(H_{\mathrm{s}} / h\right)$ for each are given. 

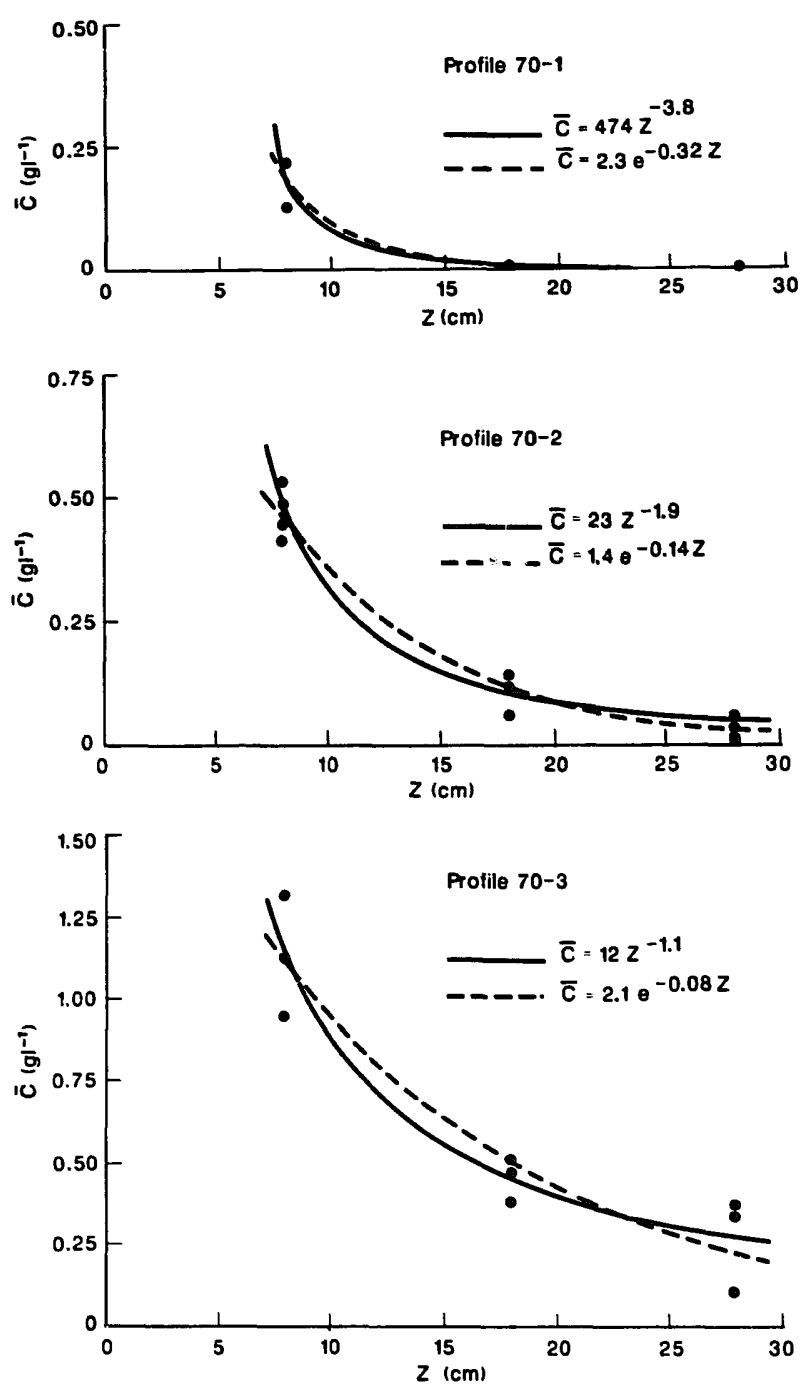

Fig. 11. Vertical profiles of the time-averaged (mean) sediment concentration $(\bar{c})$ determined for the $70 \mathrm{~m}$ station during distinct phases of storm-wave growth, Queensland Beach (87:10:25): Profile 70-1 from samples taken at $0906 \mathrm{~h}$ and $1006 \mathrm{~h}$; Profile 70-2 from samples taken at $1036 \mathrm{~h}, 1124 \mathrm{~h}$, $1224 \mathrm{~h}$ and $1254 \mathrm{~h}$; Profile 70-3 from samples taken at $1324 \mathrm{~h}$, $1354 \mathrm{~h}$ and $1424 \mathrm{~h}$. Average near-bed orbital speeds $\left(u_{\mathrm{s}}\right)$ were $0.15,0.23$ and $0.36 \mathrm{~m} \mathrm{~s}^{-1}$, respectively. Note: least squares exponential and power functions are shown.

mean cross-shore current varied with depth in a similar manner to the orbital speed, with distinct subpopulations in both deeper ( $>2.75 \mathrm{~m}$ of water) and shallower ( $<2.00 \mathrm{~m}$ of water); however, in this case the largest mean currents occurred in the shallower water ( $<2 \mathrm{~m}$ of water). These patterns indicate that both orbital and mean currents are constrained by the spatial pattern of wave shoaling, breaking and reformation across the shoreface, and further imply that most wave breaking took place in water depths between 2 and $2.75 \mathrm{~m}$ during this storm. The time-averaged sediment concentraion $(\langle c\rangle)$ and the mean sediment transport rate, $(\bar{u} \bar{c})$, also decreased with increasing depth in the wave shoaling region $(2.75$ to $5.25 \mathrm{~m})$. This is only to be expected if the orbital speeds, which control sediment re-suspension to a large degree, also decrease with depth.

\section{Net suspended sediment transport rates}

It is evident from the foregoing analyses, that as incident wave energy increased and decreased so did the magnitudes of the sediment transport contributions attributable to the various frequency components in the energy spectrum, including the mean currents. However, of importance to the sediment mass balance on the shoreface is the relative contribution of these transport components to the local net suspended sediment transport rate; of special significance is the spatial and temporal variation of these discrete transport components.

\section{Vertical structure of sediment transport in time and space}

Figure 13 provides a succinct summary of the contributions to the total net suspended sediment transport rate of each of the transport components over both space and time. Conditions of both nonbreaking and breaking waves are illustrated. The mean and oscillatory sediment transport rates are plotted, together with the total net sediment transport rates computed using both the instantaneous cross-products and the sum of the mean and net oscillatory components.

Transport profiles under non-breaking waves showed invariably that only a small amount of net sediment transport was occurring, restricted to elevations close to the bed and directed consistently onshore. In Fig. 13a note the near-zero net sediment transport throughout the lower water column at the $100 \mathrm{~m}$ and $90 \mathrm{~m}$ stations, with significant net transport beginning at the $70 \mathrm{~m}$ station and restricted here to within $0.08 \mathrm{~m}$ of the bed. This indicates that an onshore transport at 

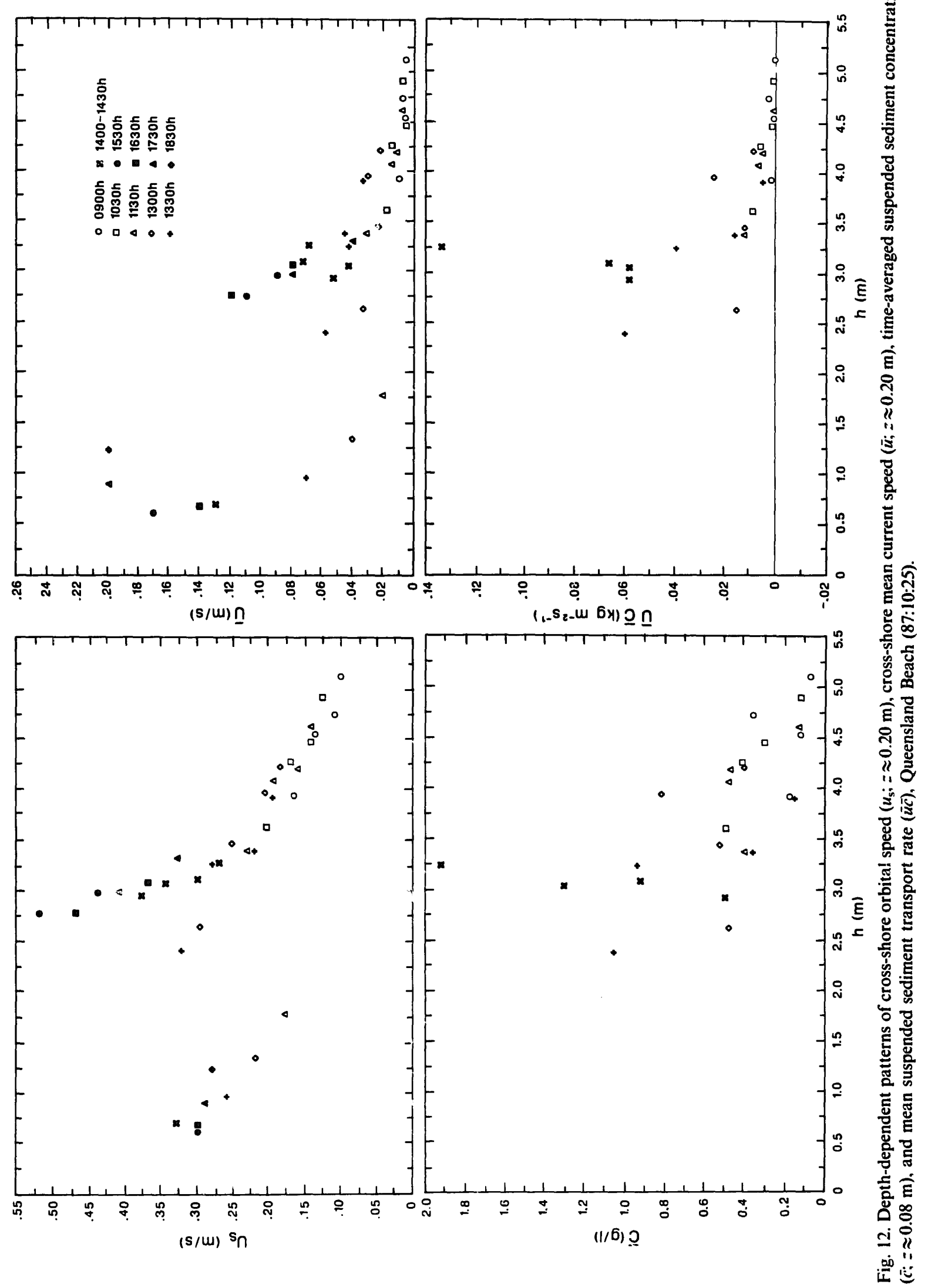


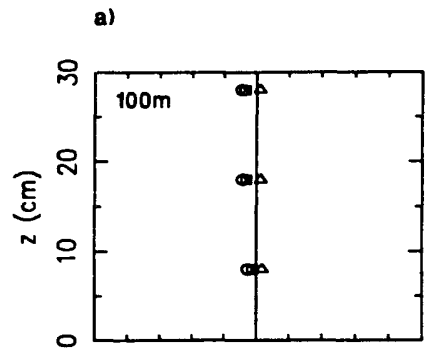

b)

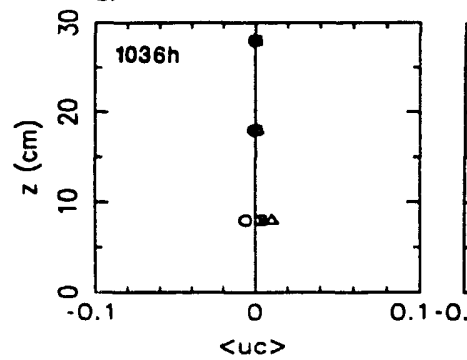

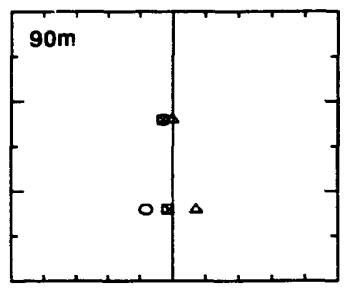

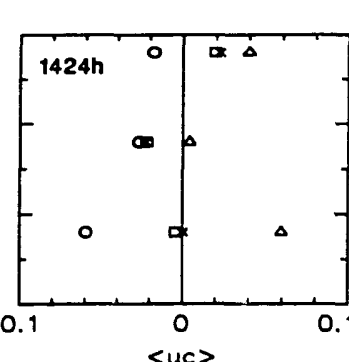

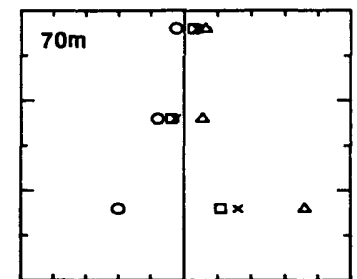

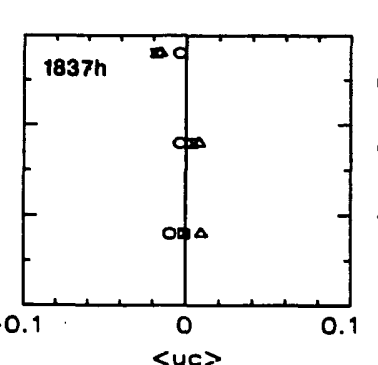

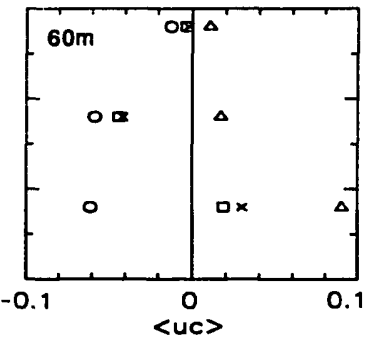

a $\langle u c\rangle_{\text {totol }}=1 / n \Sigma u c$

$0\langle u c\rangle_{\text {mean }}=1 / n \sum u+1 / n \sum c$

$\Delta\langle u c\rangle_{\text {osc }}=\Delta f / f_{c} \Sigma C_{u c}(f)$

$x\langle u c\rangle_{\text {:otal }}=\langle u c\rangle_{\text {mean }}+\langle u c\rangle_{\text {oac }}$

Fig. 13. Vertical structure of the time-averaged suspended sediment transport components, Queensland Beach (87:10:25): (a) spatial variability at $1324 \mathrm{~h}$; (b) temporal variability at the $70 \mathrm{~m}$ station through the growth, peak and decay of the storm.

wind-wave frequencies, as observed in the cospectra, dominates the net suspension transport under these conditions. Transport profiles associated with waves which were breaking occasionally by spilling, show that, while the net oscillatory sediment transport was generally directed onshore, the mean sediment transport was directed offshore at all elevations (Fig. 13a, $60 \mathrm{~m}$ station; Fig. 13b, $1424 \mathrm{~h}$ ). The opposing and near-equal mean and osciliatory transports often result in an approximate balance in the local net sediment transport; the vertical structure at $70 \mathrm{~m}$, for example (Fig. 13a), was characterized by onshore, waveinduced transport at 0.08 and $0.28 \mathrm{~m}$, while at mid-depth $(0.18 \mathrm{~m})$ the offshore transport due to mean currents dominates. In contrast, at the $90 \mathrm{~m}$ station, the net oscillatory transport at $0.08 \mathrm{~m}$ was significantly smaller than at $70 \mathrm{~m}$; this combined with the effects of an offshore mean current, produced an offshore net transport. At the $0.18 \mathrm{~m}$ elevation, both the oscillatory and the mean transports are offshore at the $90 \mathrm{~m}$ station, resulting also in an offshore net sediment transport. These observations indicate that the total net transport at any elevation depends critically upon the relative magnitudes of both the net oscillatory and mean sediment transport components at that elevation; a balanced transport can therefore be achieved even when individual components are large.

\section{Temporal variability in the net suspended sediment} transport

During the early part of the storm, the net sediment transport was directed offshore at $0.18 \mathrm{~m}$ above the bed at all locations (Fig. 13a), and appeared to increase in magnitude as the storm progressed (Fig. 13b). This offshore transport was largest at the $90 \mathrm{~m}$ station as a result of the strong mean currents occurring at this location coupled with the relatively weak net oscillatory transport in the deeper water. In contrast, the total net sediment transport at $0.08 \mathrm{~m}$ was directed onshore throughout the early part of the storm at the $60 \mathrm{~m}$ station. In deeper water, where the oscillatory currents were weaker, the onshore and offshore components of transport were nearly in balance; once the mean sediment transport became large enough to offset the net oscillatory transport, then the offshore transport of sediment became dominant.

Unfortunately, during the period of time when wave breaking was most intense and when timeaveraged cross-shore currents were at a maximum 
$(1500-1600 \mathrm{~h})$, the $60 \mathrm{~m}$ sediment transport station ceased to function, and the sediment concentration measurements at other locations were contaminated by seaweed. Following the peak of the storm (1837-2355 h), the net oscillatory and meanii sediment transports returned to near zero at the $70 \mathrm{~m}$ and $90 \mathrm{~m}$ stations, even though orbital velocities remained high $\left(u_{\mathrm{s}}=0.2-0.5 \mathrm{~m} \mathrm{~s}^{-1}\right)$ and sediment concentrations were still large (upto $10 \mathrm{~g} \mathrm{1}^{-1}$ ) during individual wave cycles. This somewhat truncated time-series neve:thelers suggests that the greatest potential for onshore suspended sediment transport is restricted to within $0.10 \mathrm{~m}$ of the bed; furthermore it is largest just seaward of wave breaking, where the net oscillatory transport is largest and directed onshore as a result of the large skewness and asymmetry in the shoaling waves (cf. Doering, 1988). On the other hand, a net offshore sediment transport dominates at those locations where the time-averaged mean currents are relatively large and where the net oscillatory transport is relatively small; at Queensland Beach this occurred between 70 and $90 \mathrm{~m}$ offshore, where wind wave oscillations were large, but still nearsymmetrical, and where the mean currents were still relatively large.

\section{Sediment re-activation, volume flux and erosion- accretion patterns}

Waves and currents during the storm event of October 25/26, 1987, caused substantial sediment re-activation at least to the seaward limit of the experimental array at Queensland Beach. The maximum depth-of-activity recorded was $0.25 \mathrm{~m}$ at the $60 \mathrm{~m}$ station (Fig. 14); however, re-activation in the surf zone was so large that all depth-of-activity rods were lost landward of $50 \mathrm{~m}$. Indeed, the sediment transport station at $60 \mathrm{~m}$ collapsed during the storm at least in part due to entrainment of sediment. The depth-of-activity appears to have decreased monotonically with distance offshore from approximately $0.20 \mathrm{~m}$ near the $70 \mathrm{~m}$ station to less than $0.02 \mathrm{~m}$ at a distance of $170 \mathrm{~m}$ offshore (Fig. 14). Such a strong correlation with offshore distance is to be expected as water depth changes, and has been measured previously across a shoal- ing slope by Greenwood and Mittler (1984, fig. 8, p. 92).

The time-integrated patterns of erosion and accretion for this event were somewhat more complex than the pattern of depth-of-activity. In general, seaward of the $60 \mathrm{~m}$ station (primarily a zone of wave shoaling during this storm) the shoreface was subjected to small amounts of erosion, with not more than $0.10 \mathrm{~m}$ of sediment being removed from the pre-storm surface. Bed elevation change landward of $60 \mathrm{~m}$, in contrast, was more substantial. Upto $0.20 \mathrm{~m}$ of accretion occurred in the inner part of the surf zone at its maximum extent (between 15 and $50 \mathrm{~m}$ offshore) and upto $0.30 \mathrm{~m}$ of erosion occurred on the upper foreshore (between the baseline and $15 \mathrm{~m}$ offshore). Beach observations during the storm confirmied this pattern: a $5 \mathrm{~m}$ wide barid of cobbles became progressively exposed by erosion of the upper foreshore at high tide during both the early part of the storm (0900-1100 h) and following the storm peak (2000-2100 h). Furthermore, current meters deployed initially at a nominal elevation of $0.20 \mathrm{~m}$ at the 20 and $30 \mathrm{~m}$ stations were almost completely buried by sediment when the lower foreshore was exposed during low tide (1500$0200 \mathrm{~h}$ on Oct. 26); also the current meter at the $45 \mathrm{~m}$ station was approximately $0.10 \mathrm{~m}$ closer to the bed following the storm than it was prior to the event, confirming that this amount of accretion had occurred in the area.

The time-integrated net volume flux of sediment (INVF), computed for a unit width of beach between 0 and $170 \mathrm{~m}$ offshore using both survey and depth-of-activity data, indicates only a small net gain of sediment of approximately $8 \mathrm{~m}^{3}$. A net gain of approximately $56 \mathrm{~m}^{3}$ of sediment in the inner part of the surf zone was almost completely balanced by net sediment losses of approximately $12 \mathrm{~m}^{3}$ from the upper foreshore and approximately $36 \mathrm{~m}^{3}$ from the shoaling zone. It is clear that sediment from the upper foreshore was transported downslope and deposited in the inner part of the surf zone; it would appear also that sediment eroded from the shoaling wave zone was transported landward and also deposited in the surf zone (in this case the outer part). 

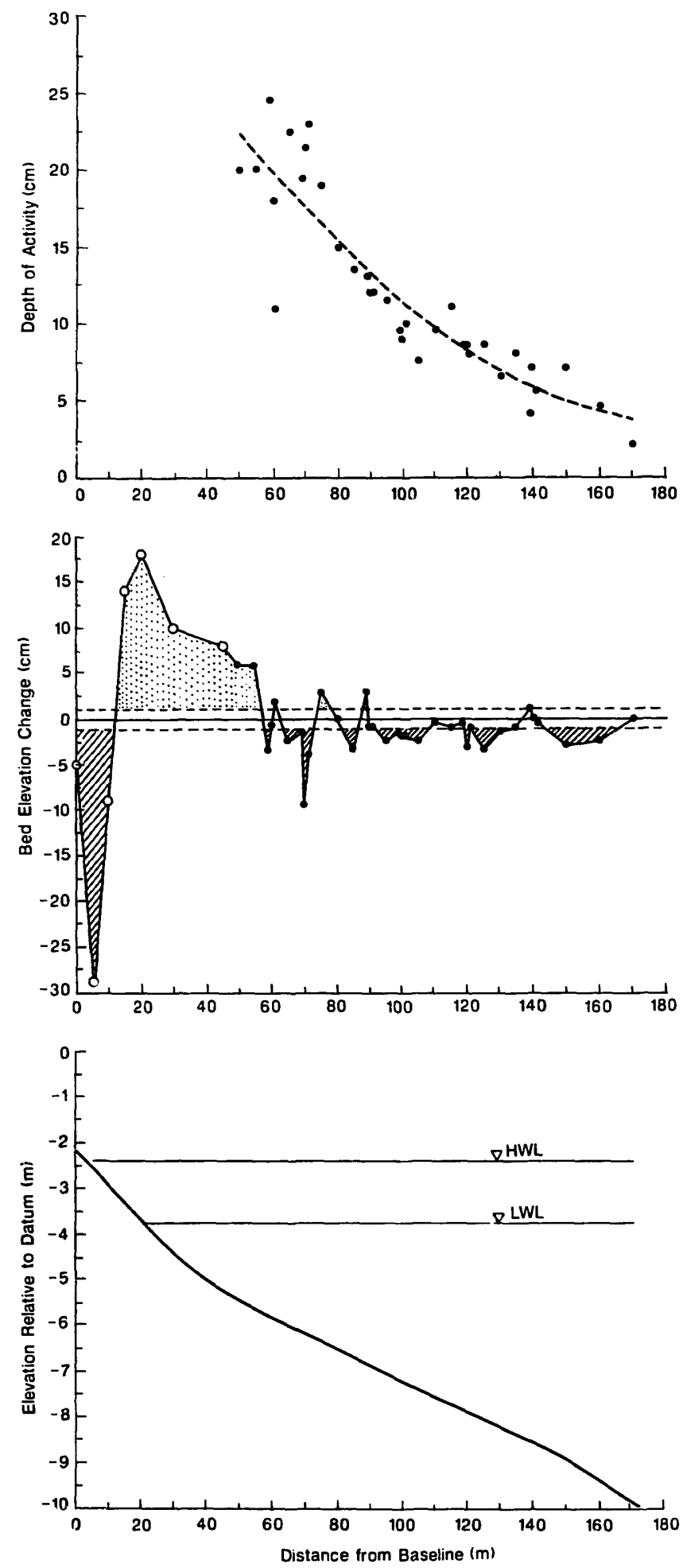

Fig. 14. Variation in elevation, bed-elevation change and depth-of-activity across the shoreface. Note: stippling represents accretion and cross-hatching represerts erosion; the horizontal dashed lines on the bed elevation change graph represent the estimated measurement error band of $\pm 1 \mathrm{~cm}$. Solid circles are rod measurements, open circles are survey measurements; the dashed line through the depth-of-activity data is the best fit (second order) curve. 


\section{Discussion}

The measurements and analyses documented above provide new insights into both the spatial and temporal patterns of suspended sediment transport under wave-induced currents across a non-barred shoreface during a storm event. In particular, the critical importance of both oscillatory currents of various frequencies and the timeaveraged cross-shore currents to the net suspended sediment transnort has been demonstrated.

Co-spectral analyses of the near-bed, cross-shore velocity and suspended sediment concentration vectors reveal that shoaling waves produce a relatively strong onshore transport at wind-wave frequencies, which contrasts with a weaker offshore transport of sediment at frequencies lower than those of the wind-wave band. A similar pattern was suggested previously by Huntley and Hanes (1987) from a more restricted dataset. It is now clear that the sedimentary response to wave forcing depends critically upon not only the instantaneous velocity associated with the large amplitude, short period wind waves, but also upon any low frequency modulation associated with wave groups. Larger onshore oscillatory currents associated with the passage of skewed, asymmetric incident waves, lead not only to the mobilization and suspension of sediment, but also to a net onshore transport (Doering and Bowen, 1989; Greenwood et al., 1990, 1991 a,b; Osborne et al., 1990). The smaller offshore net transport associated with low frequency oscillations is due to a "flux coupling" between the offshore flow associated with the bound long wave, forced by the "groupiness" in the incident waves (Longuet-Higgins and Stewart, 1962; Wells, 1967) and the large sediment concentrations associated with re-suspension by the larger waves constituting the wave group. Doering and Bowen (1989) suggested that a large onshore transport observed at wind-wave frequencies reflects the greater ability of the onshore currents to entrain sediment than the weaker offshore currents; they further implied that most of the sediment entrained in each half-wave cycle fell out of suspension before the flow reversed. Measurements from this study, however, suggest that the latter implication is not a requirement for the co-spectral structure observed, since the minimum time required for sediment to settle from $0.08 \mathrm{~m}$, for example, is on average greater than or equal to, half a wave period (assuming a still water settling velocity of approximately $2 \mathrm{~cm} \mathrm{~s}^{-1}$ for a median grain size of $0.18 \mathrm{~mm}$ and wave periods of 3-4 s).

Examination of vertical profiles of the components contributing to the net suspended sediment transport rates indicates that it is the "relative magnitudes" of the mean and oscillatory sediment transport, which play a critical role in the local sediment transport balance. Furthermore, suspended sediment flux shows a clear vertical stratification. The net oscillatory sediment transport is most often onshore under wave shoaling and may dominate the total net transport both near the bed and also higher in the water column; in contrast, the mean sediment transport is most frequently offshore and may dominate the sediment flux at mid-depth.

As might have been expected, the greatest potential for net suspended sediment transport coincides with the time of maximum kinetic energy input (i.e. the storm peak), when waves are breaking or near breaking over large sections of the upper shoreface. The data from this non-barred ervironment indicate that the largest net onshore transport occurs just seaward of the point of wave breaking, where the net oscillatory transport is largest and directed onshore under strongly skewed, asymmetric shoaling waves. On the other hand, net offshore sediment transport occurs in zones of relatively strong mean currents and relatively weak oscillatory currents; these occur both seaward and landward of the initial breaker line.

It is also evident from this study that while substantial amounts of sediment re-activation may occur, changes to the nearshore morphology may be relatively minor (see also Greenwood, 1987). The observed erosion/accretion patterns suggest that the strong rip currents observed in the inner part of the surf zone ( within $45 \mathrm{~m}$ of the shoreline) may have been responsible for the offshore transport of material eroded from the beach face. Sediment from the upper beach face appears to have been moved downslope and deposited between 15 and $60 \mathrm{~m}$ offshore. A relatively strong onshore transport driven by shoaling waves during 
the early and late parts of the storm (as observed at $60 \mathrm{~m}$ in the early part of the storm) may have balanced the seaward transports from the inner surf zone, resulting in the observed accretion in the surf zone; however, accretion in this zone did not result in the development of a barred profile.

The relative importance of mean and net oscillatory sediment transport to the total net sediment transport in the shoaling zone are uncertain for the storm peak. It is possible that the net oscillatory sediment transport increased as the water depth decreased with the falling tide and as the extent of the surf zone increased. Since no substantial net change in the bed elevation occurred in this area, even though the depth-of-activity was in excess of $0.10 \mathrm{~m}$, it seems possible that sediment may have been carried seaward from this area by the dominant mean currents in the early part of the storm, and later returned by onshore oscillatory transports during the storm peak. It is thus important to note that a local sediment balance over a storm event may also be achieved by temporal changes in local sediment transport rates and directions, as well as spatial changes.

\section{Conclusions}

Field measurements reveal that important contributors to the cross-shore transport of suspended sediment under combined waves and currents across a non-barred shoreface are:

(1) "quasi-steady" mean currents, with characteristics typical of a set-up driven undertow;

(2) oscillatory currents at wind-wave frequencies;

(3) oscillatory currents at low frequencies outside the wind-wave band and forced by group bound long waves.

The net sediment transport rate controlling both the local sediment balance and the morphological response is a reflection of the relative magnitudes and directions of transport attributable to these components. A balanced transport state can therefore be achieved even when the individual components are large.

The sediment transport attributable to mean currents is frequently halanced by that attributable to net oscillatory currents. The net oscillatory sediment transport rate is most frequently domi- nated by the wind-wave component (at least outside the surf zone) and is coincident with the direction of wave propagation; in contrast, the mean sediment transport rate is predominantly downwave or offshore driven frequently by undertows.

A distinct vertical structure in the "total" net sediment transport rate is identifiable in the nearbed water column in the region of shoaling waves; this results from a time-dependency between horizontal velocity (stress) and sediment concentration which varies with elevation. A net onshore sediment transport (attributable to oscillatory currents) occurs both near the bed and higher in the water column, while a net offshore sediment transport (attributable to mean currents) dominates the middle portion of the lower water column. Thus a transport balance can be achieved through vertical integration of the transport rates throughout the lower water column. However, measurements with greater spatial resolution (of both velocity anci concentration) are required to confirm these patterns.

The notion of a balanced sediment flux across the full shoreface, resulting from interactions between the discrete components of suspended sediment transport, is supported not only by the local net sediment transport rates but also by the spatial variability in suspended sediment transport and by measured erosion and accretion patterns. The net onshore sediment transport at wind-wave frequencies was greatest just seaward of wave breaking and decreased offshore. A net offshore sediment transport occurred in areas of relatively strong mean currents and relatively weak oscillatory currents, i.e. both in the seaward part of the shoaling wave zone and landward of the point of initial wave breaking.

These conclusions suggest that sediment transport predictors based on the simple cross-products of time-averaged mean flows and mean concentrations (e.g. Dally and Dean, 1984; Deigaard et al., 1986) cannot be successful, at least not for the suspended load. Furthermore, even the best physically-based models for sediment transport (e.g. Bowen, 1980a; Bailard, 1981; Roelvink and Stive, 1989) which include contributions to the velocity field from both wave and current induced flows, 
still assume time and depth-integrated terms and therefore, will not be able to achieve more than a qualitative agreement with observed sediment behaviour. The spatial (horizontal and vertical) and temporal variations in suspended sediment transport identified by this research suggest that important fluid-sediment interactions occur close to the boundary which are critical to determining net sediment transport rates. Therefore, accurate field measurements of both the velocity and sediment concentration near the bed (within the wavecurrent boundary layer) are required to understand the flux of sediment in the near bed region.

\section{Acknowledgements}

This is a contribution from the Canadian Coastal Sediment Transport Programme (CCOAST) supported by Strategic Grants from the Natural Sciences and Engineering Research Council of Canada awarded to B. Greenwood and A.J. Bowen. P.D. Osborne acknowledges support in the form of a post-graduate scholarship from the same body. We would like to thank R. Brander, J. Ollerhead, N. Sela, Xu Zhiming and A. Hincenbergs, from the University of Toronto, and $\mathrm{D}$. Hazen, S. McLean, R. Tatavarti, and K. Lewis from Dalhousie University for their assistance in data collsction and processing; Dr. David Huntley is to be thasked for fruitful discussion. The support of the Academic Workshops and Graphics Department at the Scarborough Campus of the University of Toronto is also gratefully acknowledged.

\section{References}

Bagnold, R.A., 1963. Mechanics of marine sedimentation. In: M.N. Hill (Editor), The Sea. Wiley-Interscience, New York, 3, p. 507-528.

Bagnold, R.A., 1966. An approach to the sediment transport problem from general physics. U.S. Geol. Surv. Prof. Pap., 422-1, 37 pp.

Bailard, J.A., 1981. An energetics total load sediment transport model for a plane sloping beach. J. Geophys. Res., 86: 10938- 10954

Beach, R.A. and Sternberg, R.W., 1988. Suspended sediment transport in the surf zone: response to infragravity motion. Mar. Geol., 80: 61-79.

Bowen, A.J., 1980a. Simple models of nearshore sedimentation: beach profiles and longshore bars. In: S.B. McCann (Editor),
The Coastline of Canada. Geol. Surv. Can. Pap., 80-10: 1-11.

Bowen, A.J., 1980b. Nearshore velocity measurements and beach equilibrium. Proc. Can. Coastal Conf. (Burlington, Ont.). Assoc. Comm. Res. Shoreline Erosion and Sedimentation, Natl. Res. Counc. Can., Ottawa, pp. 21-46.

$D$ and A Instruments and Engineering, 1988. Optical backscatterance turbidity monitor-Instrumentation Manual. 32 pp.

Dally, W.R. and Dean, R.G., 1984. Suspended sediment transport and beach profile evolution. J. Waterway Port Coastal Ocean Eng., 110: 15-33.

Deigaard, R., Fredsoe, J. and Hedegaard, I.B., 1986. Mathematical model for littoral drift. J. Waterway Port Coastal Ocean Eng., 112: 351-369.

Dixon, W.J. (Editor), 1985. BMDP Statistical Software, 1985 Printing. Univ. California Press, Berkeley, 734 pp.

Doering, J.C., 1988. Wave-wave interactions in the nearshore. Ph.D. Thesis, Dalhousie Univ., Halifax, N.S., 140 pp. (Unpubl.)

Doering, J.C. and Bowen, A.J., 1985. Skewness et al., the spatial distribution of some moments of the nearshore velocity field. Proc. Can. Coastal Conf. (St. John's, Nfdld.). Assoc. Comm. Res. Shoreline Erosion and Sedimentation, Natl. Res. Counc. Can., Ottawa, pp. 5-16.

Doering, J.C. and Bowen, A.J., 1989. Wave-induced flow and nearshore suspended sediment. Proc. 21st Coastal Eng. Conf. (Malaga, Spain). Am. Soc. Civ. Eng., New York, pp. 14521463.

Downing, J.P., 1983. An optical instrument for monitoring suspended particulates in ocean and laboratory. Proc. Oceans '83, (San Francisco, Calif.). IEEE and MTS, pp. 199-202.

Downing, J.P., Sternberg, R.W. and Lister, C.R.B., 1981. New instrumentation for the investigation of sediment suspension processes in the shallow marine environment. Mar. Geol., 42: 19-34.

Grant, W.D. and Madsen, O.S., 1979. Combined wave and current interaction with a rough bottom. J. Geophys. Res., 84: 1797-1808.

Greenwood, B., 1987. Sediment balance and bar morphodynamics in a rultiple bar system: Georgian Bay, Canada. In: V. Gardiner (Editor), International Geomorphology 1986 Part I. Wiley, New York, pp. 1119-1143.

Greenwood, B. and Davidson-Arnott, R.G.D., 1972. Textural variation in the sub-environments of the shallow-water wave zone, Kouchibouguac Bay, New Brunswick. Can. J. Earth Sci., 9: 679-688.

Greenwood, B. and Hale, P.B., 1980. Depth of activity sediment flux and morphological change in a barred nearshore environment. In: S.B. McCann (Editor), The Coastline of Canada. Geol. Survey Can. Pap., 80-10: 89-100.

Greenwond, B. and Mittler, P.R., 1984. Sediment flux and equilibrium slopes in a barred nearshore. Mar. Geol., 60: 79-98.

Greenwood, B. and Osborne, P.D., 1988. Vertical structure in shore-parallel flows and bed roughness. Proc. Workshop on Roughness and Friction (Toronto, Ont.). Assoc. Comm. on Shorelines, Natl. Res. Counc. Canada, Ottawa, pp. 75-91.

Greenwood, B. and Osborne, P.D., 1990a. Vertical and structure in cross-shore flows: an example of undertow and setup on a barred beach. Coastal Eng., 14: 543-580. 
Greenwood, B. and Osborne, P.D., 1990b. Equilibrium slopes aid cross-shore velocity asymmetries in a storm-dominated, barred nearshore system. Mar. Geol., 96: 211-235.

Greenwood, B. and Osborne, P.D., 1992. Sediment resuspension and wave groups: a time series approach. Proc. Workshop on Wave Groups. Assoc. Comm. on Shorelines, Natl. Res. Counc. Can., Ottawa, in press.

Greenwood, B. and Sherman, D.J., 1986. Hummocky crossstratification in the surf zone: flow parameters and bedding genesis. Sedimentology, 33: 33-45.

Greenwood, B. and Sherman, D.J., 1988. Bedforms and roughness in prototype surf zones. Proc. Workshop on Roughness and Friction. Assoc. Comm. on Shorelines, Natl. Res. Counc. Can., Ottawa, pp. 45-59.

Greenwood, B., Osborne, P.D., Bowen, A.J., Hazen, D.G. and Hay, A.E., Is." C-Coast: The Canadian Coastal Sediment Transport Programme. Proc. Can. Coastal Conf. (Kingston, Ont.). Assoc. Comm. on Shorelines, Natl. Res. Counc. Can., Ottawa, pp. 319-336.

Greenwood, B., Osborne, P.D., Bowen, A.J., Hazen, D.G. and Hay, A.E., 1991a. Nearshore sediment flux and bottom boundary dynamics. In: The Canadian Coastal Sediment Transport Programme (C-Coast). Proc. 22nd Coastal Eng. Conf. (Delft, The Netherlands). Am. Soc. Civ. Eng., New York, pp. 2227-2240.

Greenwood, B., Osborne, P.D., Bowen, A.J., Hazen, D.G. and Hay, A.E., 1991b. Measurements of suspended sediment transport in prototype shorefaces. In: The Canadian Coastal Sediment Transport Programme (C-C vast). Proc. Coastal Sediments '91. (Seattle, Wash.). Am. Soc. Civ. Eng., New York, pp. 284-289.

Guza, R.T. and Thornton, E.B., 1985. Velocity moments in nearshore. J. Waterway Port Coastal Ocean Eng., 111: 235-256.

Guza, R.T., Clifton, M.C. and Rezvani, F., 1988. Field intercomparisons of electromagnetic current meters. J. Geophys. Res., 93: 9302-9314.

Hanes, D.M. and Huntley, D.A., 1986. Continuous measurements of suspended sand concentration in a wave dominated nearshore environment. Cont. Shelf Res., 6: 585-596.

Hazen, D.G., Huntley, D.A., and Bowen, A.J., 1987. UDATS: A system for measuring nearshore processes. Proc. Oceans 87. (Halifax). IEEE, pp. 993-997.

Hazen, D.G., Doering. J.C. and Bowen. A.J., 1989. A note on a low cost pressure sensor for nearshore wave measurement. Cont. Shelf Res., 14: 85-90.

Huntley, D.A. and Hanes, D.M., 1987. Direct measurement of suspended sediment transport. Coastal Sediments '87. (New Orleans). Am. Soc. Civ. Eng., New York, pp. 723-737.

Inman, D.L. and Bowen, A.J., 1963. Flume experiments on sand transport by waves and currents. Proc. 8th Coastal Eng. Conf. Am. Soc. Civ. Eng., New York, pp. 137-150.

Jaffe, B.E., Sternberg, R.W. and Sallenger, A.H., 1985. The role of suspended sediment in shore-normal beach profile changes. Proc. 19th Coastal Eng. Conf. (Houston). Am. Soc. Civ. Eng., New York, pp. 1983-1996.

Kennedy, J.F. and Locher, F.A., 1972. Sediment suspension by water waves. In: R.E. Meyer (Editor), Waves on Beaches and Resulting Sediment Transport. Plenum, New York, pp. 249-295.

Longuet-Higgins, M.S. and Stewart, R.W., 1962. Radiation stress and mass transport in gravity waves, with application to "surf beats". J. Fluid Mech., 13: 481-504.

Nielsen, P., Svendsen, I.A. and Staub, C., 1979. Onshoreoffshore sediment movement on a beach. Proc. 16th Coastal Eng. Conf. (Hamburg). Am. Soc. Civ. Eng., New York, pp. $1475-1492$.

Nielsen, P., Green, M.O. and Coffey, F.C., 1982. Suspended sediment under waves. Coastal Studies Unit, Dept. of Geography, Univ. Sydney, Australia, Tech. Rep. 82/6, 157 pp.

Ollerhead, J. and Greenwood, B., 1990. Bedform geometry and dynamics in the upper shoreface, Bluewater Beach, Ontario, Canada. Proc. Can. Coastal Conf. (Kingston, Ont.). Assoc. Comm. on Shorelines, Natl. Res. Counc. Can., Ottawa, pp. 337-348.

Osborne, P.D., 1990. Suspended sediment transport on barred and non-barred beaches. Ph.D. Thesis, Univ. Toronto, 196 pp. (Unpubl.)

Osborne, P.D. and Greenwood, B., 1991. Set-up driven undertows on a barred beach. Proc. 22nd Coastal Eng. Conf. (Delft. The Netherlands). Am. Soc. Civ. Eng., New York, pp. 227-240.

Osborne, P.D. and Greenwood, B., 1992a. Sediment suspension under waves and currents: time scales and vertical structure. Sedimentology, (submitted).

Osborne, P.D. and Greenwood, B., 1992b. Sediment resuspension and wave groups: a spectral approach. Proc. Workshop on Wave Groups. Assoc. Comm. on Shorelines, Natl. Res. Counc. Can., Ottawa, in press.

Osborne, P.D., Greenwood, B. and Bowen, A.J., 1990. Crossshore suspended sediment transport on a non-barred beach: the role of wind waves, infragravity waves and mean flows. Proc. Can. Coastal Conf. (Kingston, Ont.). Assoc. Comm. on Shorelines, Natl. Res. Counc. Can., Ottawa, pp. 349-361.

Roelvink, J.A. and Stive, M.J.F., 1989. Bar generating crossshore flow mechanisms on a beach. J. Geophys. Res., 94: 4785-4800.

Sherman, D.J. and Greenwood, B., 1984. Boundary roughness and bedforms in the surf zone. Mar. Geol., 60: 199-218.

Simons, D.B. and Richardson, E.V., 1962. Resistance to flow in alluvial channels. Trans. Am. Soc. Civ. Eng., 127: 927-954.

Simons, D.B. and Richardson, E.V., 1966. Resistance to flow in alluvial channels. U.S. Geol. Surv. Prof. Pap., 422-J, 61 pp.

Skafel, M.G. and Krishnappan, B.G., 1984. Suspended sediment transport distribution in a wave field. J. Waterway Port Coastal and Ocean Eng. Div., Am. Soc. Civ. Eng., 110(2): 215-230.

Sleath, J.F.A., 1982. The suspension of sand by waves. J. Hydraul. Res., 20: 439-452.

Sternberg, R.W., Shi, N.C. and Downing, J.P., 1984. Field investigations of suspended sediment transport in the nearshore zone. Proc. 19th Coastal Eng. Conf. (Houston). Am. Soc. Civ. Eng., New York, pp. 1782-1798.

Wells, D.R., 1967. Beach equilibrium and second-order wave theory. J. Geophys. Res., 72: 497-504. 